\title{
ASIA AND INTERNATIONAL ORGANIZATIONS
}


Ko Swan Sik, M.C.W. Pinto, and J.J.G. Syatauw - 9789004400610

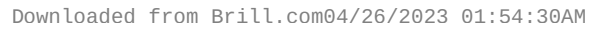


ASIAN-AFRICAN LEGAL CONSULTATIVE COMMITTEE* ANNUAL SURVEY OF ACTIVITIES 1992-1992, INCLUDING THE WORK OF ITS THIRTY-FIRST SESSION HELD IN ISLAMABAD, 25 JANUARY-1 FEBRUARY 1992**

\section{Membership and Organization}

2. Questions under Consideration by the International Law Commission

2.1. Jurisdictional Immunities of States and their Property

2.2. Law of the Non-Navigational Uses of International Watercourses

2.3. Draft Code of Crimes Against the Peace and Security of Mankind

2.4. International Liability for Injurious Consequences Arising Out of Acts

Not Prohibited by International Law

3. Legal Problems Referred to the Committee by Participating States

3.1. Status and Treatment of Refugees

3.2. Law of International Rivers

3.3. Law of the Sea

3.4. Deportation of Palestinians

3.5. Responsibility and Accountability of Former Colonial Powers

4. Matters of Common Concern Having Legal Implications

4.1. Preparation for the United Nations Conference on Environment and Development

4.2. United Nations Decade of International Law

4.3. Trade Law: Work of the Sub-Committee on International Trade Law Matters

* Edited by M.C.W. Pinto, General Editor.

** The account of the main activities of the Committee, and the main views expressed during or in connection with the Committee's thirty-first session, has been adapted from the Secretariat's Report of the Thirty-First Session (Report).

Ko Swan Sik et al. (eds.), Asian Yearbook of International Law, Volume 2, 201-253 (c) 1994 Kluwer Academic Publishers. Printed in the Netherlands 


\section{MEMBERSHIP AND ORGANIZATION}

1. There were forty-two Members of the Committee at 31 December 1992:1 Egypt, Bangladesh, China, Cyprus, Gambia, Ghana, India, Indonesia, Iran, Iraq, Japan, Jordan, Kenya, Democratic People's Republic of Korea, Republic of Korea, Kuwait, Libya, Malaysia, Mauritius, Mongolia, Nepal, Nigeria, Oman, Pakistan, Palestine, Philippines, Qatar, Saudi Arabia, Senegal, Sierra Leone, Singapore, Somalia, Sri Lanka, Sudan, Syria, Tanzania, Thailand, Turkey, Uganda, United Arab Emirates, and Yemen Arab Republic. Botswana was an Associate Member.

2. The thirty-first session of the Commitee was held at Islamabad from 25 January to 1 February 1992 at the invitation of the Government of Pakistan. Mr. AZIZ A. MUNSHI, Attorney-General of Pakistan, was elected President, and Mr. ABDUL KOROMA, Ambassador of Sierra Leone to the OAU, was elected Vice-President. Mr. MOHAMED MOSTAFA KAMAL (Arab Republic of Egypt) was elected Chairman of the Sub-Committee on International Trade Law Matters, and Mr. WON SOO KIM (Republic of Korea) was elected Rapporteur of the Sub-Committee. The Rapporteurs of the Special Meeting on Environment and Development were Mr. JAMSHED A. HAMID (Pakistan) and Mr. AMRIT ROHAN PERERA (Sri Lanka). The Secretary-General of the Committee, Mr. FRANK X. NJENGA, and members of the AALCC Secretariat were responsible for the organization of the session.

3. The Committee decided to accept the invitation of the Government of Uganda to hold its thirty-second session at Kampala (Report, p. 177).

\section{QUESTIONS UNDER CONSIDERATION BY THE INTERNATIONAL LAW COMMISSION ${ }^{2}$}

4. The Committee had before it a Secretariat document entitled Report of the Work of the International Law Commission at its Forty-Third Session (Doc. No. AALCC/XXXI/ISLAMABAD/92/4) containing surveys of the Commission's work on three topics on which it had completed phases of its work, viz. Jurisdictional immunities of States and their property, Non-navigational uses of international watercourses, and Draft code of crimes against the peace and security of mankind; as well as notes on progress made on three other topics: International liability for injurious consequences arising out of acts not prohibited by international law, Relations between States and international organizations (second part of the topic), and State responsibility. On the topic Non-navigational uses of international watercourses the Committee

1. No changes in membership took place during the period covered by the present survey. The number of members of the Committee remained 42 (see 1 AsYIL (1991) 200).

2. Cf. 1 AsYIL 201. 
also had before it a Secretariat document entitled 'The Law of International Rivers' (Doc. No. AALCC/XXXI/92/5) prepared for use in connection with the Committee's consideration of a separate item bearing that title (reported on below, at paragraphs 17-20), and containing a detailed account of the work of the International Law Commission on international watercourses.

\subsection{Jurisdictional Immunities of States and their Property}

5. The delegate of Japan, noting that some States continued to subscribe to the theory of absolute State immunity, while others felt that absolute or unlimited State immunity should not be granted in cases where a State engaged in commercial activity, called for early conclusion of a Convention containing internationally unified rules on the subject acceptable to all States (Report, pp. 153-155). The delegate of Turkey supported the Commission's suggestion to convene a diplomatic conference with a view to elaborating a convention on the topic on the basis of the Commission's draft articles. He proposed that the Commission's draft article entitled 'Contracts of employment', which allowed such contracts concluded on behalf of States to benefit from jurisdictional immunity if the employee concerned had been recruited to perform services associated with the exercise of governmental authority, should be amended. He said that the criterion to be applied here should not be the 'exercise of governmental authority', but rather the nature of the understanding as an 'administrative contract', allowed under the legal systems of some States to benefit from jurisdictional immunity even if not strictly concluded for services associated with the exercise of governmental authority. Conceding that some States granted immunity only in respect of State contracts for services associated with the exercise of governmental authority, he thought the Commission's draft article in its present form could create contradictions between the two types of State practice (Report, pp. 155-156).

6. Observing that the draft articles that were the result of the Commission's second reading still left room for improvement, the delegate of China said that entities which are established by a State to engage in commercial transactions, and which have the capacity independently to assume civil liabilities and the right to own and dispose of property, should not be included within the definition of the term 'State'. State enterprises and corporations engaging in economic and trade activities had legal personalities distinct from that of the State, and inclusion by the Special Rapporteur of a provision that made that distinction explicit had marked a major improvement on the draft articles adopted on first reading. As to the core article of the draft entitled 'State immunity', he favoured deletion of the words at the end of the text placed in square brackets, which would subject immunity not only to the provisions of the present articles but also to "the relevant rules of general international law]', since they could give rise to a one-sided and unduly liberal interpretation of the draft article. He also favoured deletion from the draft of articles entitled 'Fiscal matters' and 'Case of nationalization', which, in his view, dealt with matters falling within the prerogatives of sovereign States. Similar considerations led him to object to retention of the 
draft article entitled 'Personal injuries and damage to property', which would allow the courts of one State to determine whether or not an act or omission was 'attributable' to another State, and would, thus, in his view, be inconsistent with principles of State sovereignty and sovereign equality. Relief for such physical injury or damage to tangible property was to be sought entirely through diplomatic channels or insurance. Finally, as to part IV of the draft on State immunity from measures of constraint in connection with court proceedings, he said that immunity of State property from execution had long been established and recognized in international law and international relations. He could support the basic principle of the draft i.e. waiver of State immunity from jurisdiction does not mean waiver of State immunity from measures of constraint. Attachment or arrest could only be executed against State property with the express consent of the State concerned (Report, pp. 160-162).

\subsection{Law of the Non-Navigational Uses of International Watercourses}

7. The delegate of India said that the needs of a State through which an international river flowed should not be ignored. However, recognition of the needs of riparian States did not vitiate the need for co-operation among them. Shared interest, rather than legal obligation should, in his view, be the basis of such co-operation (Report, p. 163).

8. The delegate of Turkey, welcoming inclusion in the draft of a provision requiring Watercourse States to "utilize an international watercourse in an equitable and reasonable manner ... In particular ... with a view to attaining optimum utilization thereof', said that, in his view, not all the draft articles were consistent with it. His main criticism, however, was that the draft articles seemed to emphasize the 'environmental damage' aspect of the topic far more than the development needs of States, which, since the 1972 Stockholm Conference, had been the priority issue for the developing countries. He felt that definition of the term 'watercourse' so as to include not only surface water but also ground water, was likely to make the task of the Commission unduly complicated (Report, pp. 156-157).

9. The delegate of Syria made specific proposals for amendment of draft articles dealing with the general obligation to co-operate, regular exchange of data and information and the obligation not to cause appreciable harm, while the delegate of Jordan said that the diversion of the waters of the River Jordan by Israel contravened specific provisions of the draft articles (Report, pp. $158-159,164)$.

\subsection{Draft Code of Crimes Against the Peace and Security of Mankind}

10. The delegate of Kuwait called for the establishment of an independent international tribunal that would deal with crimes committed by a person in a foreign country, and urged that war crimes such as the killing and violation 
of human rights of innocent civilians, as well as damage to the infrastructure of a State and other injurious consequences of an invasion of foreign territory, should be subject to special punishment, including partial or complete confiscation of wealth taken unlawfully (Report, p. 152). Welcoming completion by the Commission of its first reading of the Draft Code, the delegate of Japan urged Member States to submit comments and indicate guidelines to the Commission keeping in view what he considered to be three goals of the international community, viz. (i) to define in a clear and detailed manner, in a Convention or other document, what constitutes a crime and criminal responsibility; (ii) to establish a mechanism, such as an international criminal court, which would have jurisdiction over the prosecution and punishment of such crimes and which would apply substantive and procedural rules to the prosecution of individuals; and (iii) to ensure wide acceptance of such a mechanism by the international community as a whole (Report, $\mathrm{p}$. 155).

11. The delegate of Turkey, emphasizing that categories of crimes to be covered by the Code should be both recognized as such by the entire international community, and clearly defined so as to leave no room for subjective or politically motivated interpretations of terms, doubted that the draft as it stood satisfied those criteria (Report, p. 157). The delegate of Sudan said that acts of rebel movements, such as recruitment of children of tender years for military duty, were crimes against humanity and should be covered by the Code, while the delegate of Sri Lanka called for recognition of 'narco-terrorism' and illicit arms transfers as crimes punishable under the Code, and the delegate of the United Arab Emirates proposed that 'deportation' be expressly included in the article of the Code enumerating acts comprised in the crime of apartheid. The delegate of India said that the Code should contain provision for exemplary punishment of individuals found guilty of offences against the peace and security of mankind (Report, pp. 163-165).

\subsection{International Liability for Injurious Consequences Arising Out of Acts Not Prohibited by International Law}

12. The delegate of Kuwait noted that the topic had gained significantly in importance through its links with questions relating to environmental damage (Report, p. 151). The delegate of Turkey, expressing his preference for giving the draft articles the form of a framework Convention, noted the need for appropriate provisions concerning dangerous substances, disposal of hazardous waste and injurious consequences arising from nuclear activities. The articles should, in his view, contain a general definition of dangerous substances, rather than a list of them (Report, pp. 157-158).

\section{Decision 1 of the Committee}

13. Having noted the recommendations of the International Law Commission on topics which it might be asked to take up for consideration in the 
future (Doc. No. AALCC/XXXI/ISLAMABAD/92/4, at page 3) the Committee, inter alia, decided to request the Commission to take up as a priority item the topic 'Legal aspects of the protection of the environment of areas not subject to national jurisdiction (global commons)' (Report, pp. 105-106).

\section{LEGAL PROBLEMS REFERRED TO THE COMMITTEE BY PARTICIPATING STATES}

\subsection{Status and Treatment of Refugees ${ }^{3}$}

14. The Committee had before it the following documents prepared by the Secretariat: 'Rights and duties of a refugee in the first country of asylum: principle of non-refoulement' (Doc. No. AALCC/XXXI/ISLAMABAD/92/ 7), which discusses the latter principle as a generally recognized principle of law and its application in State practice; 'Status and treatment of refugees: a note on the establishment of a safety zone in the country of origin for displaced persons' (Doc. No. AALCC/XXXI/92/8), which analyses the status of persons seeking asylum in such a safety zone, the issue of domestic jurisdiction over such a zone, the status of the zone and its operation; and 'Report on the AALCC-UNHCR Workshop on international refugee and humanitarian law in the Asian-African region, held in New Delhi from 24 to 26 October 1991' (Doc. No. AALCC/XXXI/ISLAMABAD/92/9).

15. The report on the AALCC-UNHCR Workshop lists the following points as having emerged from its discussions:

\section{'THE WORKSHOP}

- Recalled the contributions made by the Asian-African Legal Consultative Committee to the development of International Refugee Law, particularly its Bangkok Principles of 1966.

- Reiterated that the Bangkok Principles though recommendatory in nature have become the cornerstone of the State Practice of Member States in the Asian-African Region.

- Noted that the Bangkok Principles do not have legal enforceability, yet they have guided States in responding to the refugee problem in the Asian-African Region.

- Urged the Asian-African States to move a step forward by considering adherence to the 1951 Convention relating to the Status of Refugees and/or the 1967 Protocol.

- Noted with concern the magnitude and complexity of the contemporary refugee problem and recognised the challenges which needed innovative solutions and concerted efforts both at international and regional levels.

- Reaffirmed the importance of international cooperation and solidarity through the Burden Sharing Principles as adopted at the 26th Session of the Asian African Legal Consultative Committee at Bangkok in 1987 and of prompt inter-national assistance to relieve the burden of States faced with large scale influx of refugees.

3. Cf. 1 AsYIL (1991) 202. 
- Recognised that voluntary repatriation of refugees to their countries of origin when the situation so warrants, is the most desirable and durable solution to the refugee problem.

- Emphasised the importance of reintegration assistance in the country of origin to ensure that voluntary repatriation would be effective and that refugees who have returned home are not compelled to leave again because of deprivation.

- Stressed that most of the refugee problems are closely linked with the violation of human rights and, to some extent, economic deprivation in the countries of origin and, therefore, urged those countries to take concrete measures to prevent any refugee outflow.

- Reaffirmed the responsibility of the receiving countries to provide security and protection to the refugees including adherence to the universal principle of nonrefoulement.

- Reaffirmed also the responsibility of the countries of origin to provide security and safety to their citizens on their return.

- In particular stressed the importance for the countries of origin to accept the responsibility to receive their citizens as soon as the conditions that created the refugee situation cease.

- Stressed the need to further develop international law relating to refugees taking into account the particularity of the Asian-African region in order to resolve the current problems by granting maximum civil, political, economic, social and cultural rights to all refugees without discrimination on the grounds of sex, colour, race, religion, nationality, etc.

- Recognised in particular the vulnerability of refugee women and children, whether accompanied or not, and the need for special measures to ensure improvement of their situation and the promotion of their family unity.

- Recognised the role of UNHCR in the quest for durable solutions to the refugee problem and called upon the Member States of the Asian-African Legal Consultative Committee to extend their fullest cooperation in all respects.

- Expressed grave concern about the situation of internally displaced persons who are in a refugee like situation, and thus not covered by the protection of any regional and international legal instruments and stressed the necessity that the State of origin should extend all possible humanitarian assistance to such persons and that international humanitarian organisations with the consent and collaboration of the States of origin be enabled to extend their help to such persons.

- Recommended the Asian-African Legal Consultative Committee to consider the possibility of preparation of model legislation with the objective of assisting Member States in the enactment of national laws on refugees.'

\section{Decision 2 of the Committee}

16. Following a discussion of the item during which several delegates described the experience gained in their countries in dealing with and caring for refugees (Report, pp. 188-195), the Committee decided, inter alia, to endorse the recommendations adopted by the AALCC-UNHCR New Delhi Workshop; to approve the suggestion to prepare model legislation in cooperation with the Office of the United Nations High Commission for Refugees with the objective of assisting Member States in enacting appropriate national legislation on refugees; and to place an item entitled 'Safety Zones for Refugees' on the agenda of its thirty-second session, directing the Secretariat to update its study on the subject, and to cover as well the question how to minimize and remove the causes of flows of refugees. The Com- 
mittee expressed the hope that Member States of the AALCC would adhere to the 1951 Convention relating to the Status of Refugees and its 1967 Protocol (Report, p. 107).

\subsection{Law of International Rivers ${ }^{4}$}

17. The Committee had before it a Secretariat document entitled 'The law of international rivers' (Doc. No. AALCC/XXXI/ISLAMABAD/92/5). Referred to the Committee in 1966 by Iraq (concerned with defining the term 'international river', and clarifying rules relating to the utilization of the waters of such rivers for purposes not connected with navigation) and by Pakistan (concerned with clarifying the rights of lower riparian States), this item serves (1) to focus discussion on areas of importance to Member States that are not likely to be covered by the International Law Commission's work on 'The law of the non-navigational uses of international watercourses' (e.g. the five areas noted at p. 7 of the Secretariat document), as well as (2) to assist Members to monitor and formulate their views concerning progress of the work of the International Law Commission (summarized on pp $7 \mathrm{ff}$. of the Secretariat document).

18. The delegate of Turkey expressed concern that the concept 'watercourse' currently used in drafts before the International Law Commission to mean a 'system of interrelated hydrological components' might be too broad, as it included glaciers, canals and, in particular, groundwaters. As to the last, which could be categorized as 'free groundwaters' and 'confined groundwaters', not only would the collection and application of data be difficult and time-consuming, but also the absence of State practice regarding them could make identification of the applicable legal principles impossible. Moreover, a concept that could imply international regulation of all components of a 'watercourse' merely on the basis of the physical relationship between them, and even if one or more of them were within the territory of a sovereign State, could be seen as contradicting the accepted principle of international law concerning permanent sovereignty of States over their natural resources, and inconsistent with the rights of States to use their resources in accordance with their national priorities and interests (Report, pp. 166-167).

19. The delegate of Jordan, emphasizing the need of the peoples of the Middle East in relation to underground waters, said that the harm being caused to the sources of those waters through their indiscriminate use had become a major cause of differences in the occupied Arab territories. Accordingly, he urged that the Committee adopt an appropriate definition of the term 'underground watercourse' in anticipation of a diplomatic conference that might be convened to deal with the topic currently under consideration by the International Law Commission. The delegate of Syria, observing that in the Middle East some 71 per cent of the rivers had under-

4. Cf. 1 AsYIL (1991) 205. 
ground water sources, supported the views expressed by the delegate of Jordan, and recalled the proposals he had made for amendment of the draft articles being considered by the International Law Commission (above, para. 9) (Report, pp. 168-169).

20. The delegate of Sierra Leone, noting that only 2 per cent of fresh water resources were available for utilization, and only 1 per cent of such resources were really harnessable for the whole of humanity, said that 40 per cent of the world's population stood in dire need of fresh water. He emphasized the need for co-operation with a view to effective utilization of water resources and preventing pollution (Report, p. 169).

\section{Decision 3 of the Committee}

21. After delegations had expressed different views on whether, in view of the International Law Commission's parallel consideration of the law of the non-navigational uses of international watercourses, the Committee should maintain the item 'Law of international rivers' on its agenda in future, the Committee decided 'to inscribe the item on the agenda of its next session to facilitate substantive discussion on the topic', and recommended that Member States utilize the Secretariat document which was before them in preparing comments and observations to be taken into account by the Commission when it engaged in a second reading of its draft articles (Report, p. 108).

\subsection{Law of the Sea}

22. The Committee had before it a Secretariat document entitled 'Law of the sea' (Doc. No. AALCC/XXXI/92/ISLAMABAD/10) containing a summary of the work of the Preparatory Commission for the International Sea-Bed Authority and for the International Tribunal for the Law of the Sea (Prepcom) at its ninth session (Kingston, Jamaica, 25 January - 22 March 1991; New York, 12-30 August 1991).

23. In an introductory statement the Assistant Secretary-General of AALCC observed that although the target date approved at the seventh session of the Commission (1989) for completion of its work, viz. summer 1991, had not been met, important steps had been taken toward that end. Two new pioneer investors had been registered (China, and Interoceanmetal Joint Organization, an entity established by inter-governmental agreement among Bulgaria, Cuba, Czechoslovakia, German Democratic Republic, Poland, Soviet Union and Vietnam), and a Training Panel (21 experts in appropriate fields drawn from different geographical regions) had been established and begun work on a training schedule, taking into account, in particular, the manpower requirements of the Enterprise. He noted that the developing countries were not satisfied with the progress of work in the Prepcom. The

5. Cf. 1 AsYIL (1991) 206. 
protracted series of Prepcom sessions had placed an intolerable financial burden on the developing countries, many of whom had stopped sending representatives to meetings, a feature which would merely have the effect of weakening their bargaining position (Report, pp. 197-198).

24. The following summary of the Assistant Secretary-General's statement appearing in the Report (pp. 198-201) mentions important aspects of the work of the Prepcom at its ninth session in 1991:

$\therefore$

(5) The Plenary dealt with a draft Agreement concerning the relationship between the United Nations and the International Sea-Bed Authority and considered a working paper on "Administrative Arrangements Structure and Financial Implications of the Authority". Another area of activity of the Plenary, he said, was related to implementation of Resolution II. Under this general heading the obligations of pioneer investors, registration of China as pioneer investor, application of East European States and Cuba and also the establishment of the training panel and its first report had been discussed.

(6) Special Commission I, in charge of problems which would be encountered by developing landbased producer States, continued consideration of the provisional conclusions of this Commission which will form the basis of its recommendations to the Authority. Many issues remained unsettled and according to the Chairman of this Commission, deliberations had come to a stage where most delegations tended to re-affirm only their respective positions. It was decided to refer the unresolved issues, to a negotiating group of 13 members presided over by the Chairman. Unfortunately certain countries persisted in reopening debate on some issues that had been completed in previous sessions and thus made the finalization of work even more difficult.

(7) In Special Commission 2 the structure of the Enterprise, transitional arrangements and rules applicable during this period were considered. The main work was concentrated on operational options with special reference to the joint venture which is considered to be the best norm for the operation of the Enterprise. It was the accepted view that in the initial stage, the joint venture offered clear advantages with respect to the transfer of technology, training, finance, processing and marketing.

(8) An important point raised in this Commission was the initiative of the Secretary General of the United Nations to convene informal consultations aimed at achieving "universality" of the Convention. The Secretary General had conducted several informal consultations with some invited States to address the problems of developed countries which have reservations on certain aspects of the deep sea-bed mining provisions of the Convention. He pointed out that many countries, some of which had ratified the Convention, and organizations including the AALCC which had contributed significantly to the work of UNCLOS III and the PREPCOM, had been marginalized in these consultations.

(9) The issues under consideration in these consultations were vast and covered the question of the Enterprise; transfer of technology; production policy; compensation fund; decision making; environmental aspects and the review Conference. These were issues on which considerable time and energy had been spent during the negotiations of UNCLOS III. All these issues were then resolved on the basis of consensus.

(10) Turning to Special Commission 3 on Sea-bed Mining Code, he said that it was able to complete a first reading of Part VIII of the draft on prospecting, exploration 
and exploitation of polymetallic nodules in the Area, dealing with protection and preservation of the marine environment from the activities in the Area. During the Summer Session this Commission had concentrated on Part X of the same draft on accounting principles and procedures.

(11) Special Commission 4 continued consideration of administrative arrangements, structure and financial implications of the International Tribunal for the Law of the Sea. There was agreement on the need for maximum economy in the establishment of the Tribunal while maintaining the highest level of its efficiency. The seat of the Tribunal remained a very important issue, as the Group of 77 held the view that if, at the latest by the receipt of the 60th instrument of ratification the Government of Germany did not accede to the Convention, the Prepcom should make arrangements for the establishment of the Tribunal in a State that has ratified or acceded to the Convention.

(12) Referring to the message of the Special Representative of the U.N. SecretaryGeneral, he said the main themes thereof were the political and economic changes that had directly or indirectly affected deep sea-bed mining since the adoption of the Convention in 1982, and the renewed efforts to achieve universal participation in the Convention.

(13) The Secretariat of the AALCC, while appreciating the efforts made toward "universality" of the Convention was of the view that this process should not be designed to amend the Convention before it comes into force and that that forum should not become a substitute for the Preparatory Commission for the Law of the Sea. He also cautioned that while the goal of universality was one that the international community shared, apart from the Charter of the United Nations and perhaps the 1949 Geneva Conventions relating to armed conflicts, there were hardly any conventions which had achieved universality. The package deal nature of the LOS Convention should be kept in mind in this regard. Besides Part XI of the Convention which deals with deep sea-bed mining in the distant future should not in any way erode the significance of the more important and immediate aspects of the Convention (Report, pp. 198-201). ...

25. Continuing, the Assistant Secretary-General recalled that the SecretaryGeneral of AALCC had participated in Pacem in Maribus XIX held by the International Ocean Institute in Lisbon in November 1991. The main objective of that meeting had been to examine the institutional mechanisms needed for sustainable development of the ocean and its resources. It had been generally acknowledged there that ocean governance as provided under the Convention should be considered as a possible model for governance in other spheres of global concern, such as energy, food and the environment.

26. The delegate of Japan said that the reason for the reluctance of many developed countries, including his own, to ratify the 1982 UN Convention on the Law of the Sea was their dissatisfaction with its provisions regulating sea-bed mining. Recalling that the resolution on the law of the sea adopted by the UN General Assembly at its 46th session (1991) had recognized that political and economic changes, including particularly a growing reliance on market principles, underscore the need to re-evaluate ... matters in the regime to be applied to the Area and its resources', he said that such developments seemed to reflect an increasing awareness of States of the need to 
adjust the Convention's deep sea-bed regime to reality. However, his Government was resolved to support the Convention against any abuses of its provisions. He felt that AALCC had an important role to play in assisting Member States in the preparation of relevant domestic legislation in conformity with the Convention' (Report, pp. 203-204).

27. The delegate of Thailand recalled that the concept of the Exclusive Economic Zone equitably balanced the rights and obligations of coastal States with those of other States in the zone. He observed that although coastal States too had obligations with respect to the zone, not many of them had indicated what fish stocks were reserved for their use, nor allowed access by other States to the surplus stocks in their Exclusive Economic Zones. Coastal States thus tended to monopolise the resources of their zones without regard to their harvesting capacities, to the detriment of mankind as a whole. As to ways and means of promoting the 'universality' of the regime established by the 1982 Convention, he proposed that the AALCC Secretariat be asked (1) to study and report on non-conformity of national legislation with the Convention; and (2) to prepare model legislation on fisheries (Report, p. 204).

28. The delegate of Republic of Korea said that his Government was giving serious consideration to the matter of ratifying the 1982 Convention. As to the informal consultations presided over by the Secretary-General of the United Nations, the latter should make every effort to dispel any misgivings expressed by some participants, thereby promoting the universality of the Convention and its entry into force (Report, p. 205). The delegate of Sri Lanka, while expressing the hope that the industrialised countries would show flexibility and ratify the Convention, so as to facilitate its entry into force, urged that fundamental issues that had been agreed upon should not be reopened (Report, p. 207).

29. The delegate of China emphasized the need to safeguard the principle of 'the common heritage of mankind' established by the Convention with the support of the developing countries, and called for the formulation of appropriate, feasible and concrete measures through consultations and negotiations, that would ensure its implementation under conditions whereby both the investor and the international community would benefit (Report, p. 205).

30. The delegate of Sierra Leone, while declaring that his Government supported the efforts being made to bring about the universality of the Convention, said that it should not be implied that the reason for failure of some countries to ratify was the existence of imbalances in the Convention. The Convention had been painstakingly negotiated over many years on the basis of reliable information supplied by reputed institutions. Progress in science and technology since then had challenged not only part XI, but also other provisions of the Convention. While no one was opposed to taking market forces into account, if those forces were not to be utilized for the benefit of the developing countries as well, the concept of the 'common heritage of mankind' could be rendered meaningless. In his view, changes to the 
Convention should be considered after it had entered into force (Report, pp. 206-207). The delegate of India, endorsing the views of the delegate of Sierra Leone, said that the 1982 Convention represented the best possible compromise that could be achieved. Observing that the Convention represented a package deal, and that no Member of AALCC wanted to change the basic principles of the Convention, he appealed for its early ratification (Report, $\mathrm{p}$. 207).

31. The delegate of Turkey wished to be recorded as reserving his position in relation to the UN Convention on the Law of the Sea, and to the work of the AALCC on the subject (Report, p. 206).

\section{Decision 4 of the Committee}

32. In its decision ${ }^{6}$ on this item (Report, pp. 108-110), the Committee, inter alia:

$\therefore$

3. Urges the Secretariat to continue its efforts to promote and ensure the entry into force of the Convention on the Law of the Sea as soon as possible particularly by Member States of the AALCC, and to continue monitoring the work of the Prepcom for International Sea-Bed Authority and for the International Tribunal of the Law of the Sea.

4. Urges the full and effective participation of the Member States in the Prepcom so as to ensure and safeguard the legitimate interests of the developing countries.

5. Reminds Member States to give timely consideration to the need for adopting a common policy and strategy for the period between the sixtieth ratification and the coming into force of the Convention in the early years of the Convention regime.

6. While appreciating the efforts for the universal acceptance of the Convention urges the Member States to guard against any premature amendment of the Convention on the Law of the Sea.

7. Decides to urge Member States to take steps to inscribe in the agenda of the forty-seventh session of the U.N. an item entitled "Establishment of a forum within the General Assembly of the United Nations for Member States to discuss matters relating to Ocean Space as a whole with a view to framing an integrated ocean policy" and further directs the Secretary General to carry out preliminary studies on the above item.

8. Urges the International Law Commission to consider inclusion in its programme of work an item entitled "Progressive development of the concept of reservation for peaceful purposes with regard to High Seas, the International Sea-bed Area, and Marine Scientific Research ...." $\ldots$

6. The delegate of Japan 'reserved [his] Government's position as a whole' in regard to this decision. 


\subsection{Deportation of Palestinians as a Violation of International Law, particularly the 1949 Geneva Convention and the Massive Immigration and Settlement of Jews in the Occupied Territory?}

33. The Committee had before it a Secretariat document entitled 'Deportation of Palestinians in violation of international law, particularly the Geneva Convention of 1949 and the massive immigration and settlement of Jews from the Soviet Union in the occupied territory' (Doc. No. AALCC/XXXI/ ISLAMABAD/92/11), which, having recalled that the item had been referred to the Committee by the Islamic Republic of Iran at its twenty-seventh session, summarized discussion of the topic at the Committee's sessions thereafter, and provides information on the policy of establishing Jewish settlements in the Arab occupied territories, the emigration of Soviet Jews to Israel, the convening of the International Peace Conference on the Middle East under the auspices of the United Nations pursuant to General Assembly resolution 45/68 adopted on 6 December 1990, the intifadah, and the Conference on Palestine held in Tehran from 19-22 October 1991 at the initiative of the Government of the Islamic Republic of Iran.

34. The delegate of Palestine describing in detail the sufferings of the Palestinian people, made special reference to (i) acts of deportation of Palestinians in violation of all norms of international law, (ii) confiscation of their property, and (iii) settling of emigrating Russian Jews in the occupied territory, as manifestations of Zionist oppression comparable to the crimes of the Nazis, and emphasized that their continuance hindered the current peace talks. Declaring that the intifadah would continue, he urged, inter alia, that the Committee (a) request the Secretary-General to follow up on, and expand, the Secretariat study so as to draw attention to the negative consequences of the facts presented, and reach a just solution, (b) study and consider the issue of deportation in the context of human rights, and (c) adopt a declaration affirming the legitimate cause and struggle of the Palestinians and denouncing the oppressive policies of the Israeli regime (Report, pp. 179-181).

35. The delegate of Iran said that deportation of Palestinians from their homeland contravened the Hague Conventions of 1907 on the laws of war, the Charter of the United Nations and the 1949 Geneva Convention Relative to the Protection of Civilian Persons in Time of War. He emphasized the negative consequences of the establishment of Jewish settlements particularly in the West Bank of the River Jordan and the Gaza Strip, including demographic alteration, the prohibition of which was gradually being accepted as a principle of international law. Noting that such acts had been dealt with by the United Nations, most recently in General Assembly resolutions 45/73 E and G, and 45/74 A, B, E and F, and in Security Council resolution 726 of 6 January 1992 condemning the expulsion of twelve

7. Cf. 1 AsYIL (1991) 213. 
Palestinians from their homeland, and demanding that the occupying power ensure their safe and immediate return, he recalled similar action taken in international and regional organizations (e.g. the Organisation of African Unity, the League of Arab States and the Non-Aligned Movement) as well as at the Conference on Palestine held in Tehran in October 1991 (Report, pp. 182-183).

36. The delegate of Syria condemned the policies of Israel, especially in the south of Lebanon. He called on Russia, taking into account the changed international circumstances, to take steps to restrict the immigration of Russian Jews, declaring that it resulted in violation of the human rights of the Palestinians (Report, p. 183).

37. The delegate of Pakistan said his Government condemned the deportation of Palestinians in violation of international law and specifically of the 1949 Geneva Convention Relative to the Protection of Civilian Persons in Time of War; Israel's policy of expansion and annexation of the occupied Arab territories including Gaza, the West Bank of the River Jordan, and the Golan heights, in particular through the establishment of new Jewish settlements; the continued occupation of the southern territories of Lebanon; the repressive measures adopted against the population of the Arab occupied territories; the persistent violation of Israel of the four Geneva Conventions of 1949 and the Hague Conventions of 1907; the desecration of Holy Places, especially the excavation adjacent to the Dome of the Rock which threatens the Holy Al-Aqsa Mosque; and forcible expulsion of Arabs from the occupied territories (Report, pp. 184-185).

38. The delegates of Sudan, Libya, China, Egypt, Indonesia, Iraq, Yemen, India, Uganda, the Democratic People's Republic of Korea, Japan, Sierra Leone, Sri Lanka, Ghana, and Jordan, and the Observer from Algeria, condemned or deplored general or specific policies or actions of Israel in regard to the Palestinians and the occupied Arab territories (Report, pp. 183-188).

39. The Observer from Russia explained that emigration of Jews from Russia had two aspects, viz. emigration of the Jewish people from Russia to Israel; and the question of settlement of those people on their arrival in Israel. He said that, as to the first aspect, emigration of Jews from Russia was in full conformity with existing international law, especially the law of human rights, which included the right of a person to leave his/her country. As to the second aspect, he emphasized that the Russian Government issued exist visas to Jews to move to Israel, not to any specific part thereof such as the occupied territories. When issuing such exit visas his Government was careful to inform emigrants of the international community's non-recognition of Israel's occupation of Arab territories, warning them that it would be illegal and dangerous to settle there (Report, pp. 186-187).

\section{Decision 5 of the Committee}

40. In its decision on this item (Report, pp. 110-112), the Committee, inter alia: 
$\therefore$

Expresses its concern at the continuing denial and deprivation of the inalienable human rights of the Palestinian people including inter alia the right of self-determination and right to return and the establishment of their independent State on their national soil;

...

Requests the Secretary-General of the Committee to continue to monitor the events and developments in the occupied territories of Palestine;

Decides to convene an inter-sessional meeting of the Committee to consider Israel's policies of immigration and settlement, if financially feasible or if an invitation to host such a meeting is received from a Member State;

Supports the just cause of the Palestinian people and the national, political and inalienable human rights of the Palestinian people;

Condemns Israeli policy in the occupied territories and the deportation of Palestinians and annexation of the Palestinian lands against the rights of Palestinian people;

Strongly condemns Israel's policy of immigration and settlement of Jews in Palestinian and other Arab occupied territories and Southern Lebanon and Syrian Golan Heights in flagrant violation and contravention of human rights; ${ }^{8}$

Demands that Israel respect the principles of international law and all international conventions which have a bearing on the matter;

Condemns also Israel's policy of appropriation and illegal exploitation of the natural resources of the occupied territories in contravention of the Principles of Permanent Sovereignty over Natural Resources;

Requests the Secretary General to study the question of the forced changes in the demographic composition of the occupied territories including Jerusalem, West Bank and the Gaza Strip;

Urges ECOSOC to request the International Court of Justice to give an Advisory Opinion on the legality of Israel's actions and policy of settlement in the occupied territories in violation of International Law and consequences of violations of U.N. Security Council Resolutions No. 242 and 338 and legal obligations of member countries of the United Nations in this matter; 9

Requests the Russian Government to take appropriate measures which the Russian Government deems just to discourage the Settlement of the Russian Jewish immigrants in the occupied territories in violation of international law. ${ }^{10}$ $\ldots$

\subsection{Responsibility and Accountability of Former Colonial Powers ${ }^{11}$}

41. This item was included on the agenda of the Committee's TwentyNinth session in March 1990 at the request of the Libyan Arab Jamahiriya (Doc. No. AALCC/XXIX/90/8). At that session, the delegate of Libya

8. The delegation of Japan expressed reservations with respect to this paragraph, since in its view southern Lebanon could not be regarded as 'occupied territory'.

9. The delegate of Japan expressed reservations with respect to this paragraph.

10. The observer from Russia expressed reservations with respect to this paragraph as it could be understood to imply restriction of emigration in violation of human rights.

11. Cf. 1 AsYIL (1991) 229. 
requested the Secretariat to examine the legal principles establishing the liability of the colonial powers, payment of compensation for the damage caused to the Libyan people and restoration of historical monuments and cultural property. The request had the support of the delegates of Sudan, Syria, Palestine, Kuwait, Saudi Arabia, Yemen Arab Republic and Egypt, the last proposing, in addition, that AALCC undertake a programme on the topic in co-operation with UNEP. The delegate of Japan doubted that the item was an appropriate one for consideration by the Committee, and expressed the view that it concerned matters of a political nature best dealt with bilaterally or multilaterally among the States concerned. The observer from Italy, while rejecting any obligation of his government on the basis of international law, expressed his government's readiness to co-operate with the Libyan Government in dealing with the problems arising out of mines that were the remnants of war. The Committee then requested the Secretariat to prepare a study on the subject, and Libya to extend all necessary assistance for the purpose.

42. The Secretariat study prepared for the Committee's Thirtieth session but not discussed then for lack of time, was before the Committee's ThirtyFirst session as Doc. No. AALCC/XXXXI/92/12. The study contains an account of the problem of the remnants of war with special reference to the situation in Libya, commencing with deportation after 1911 of several thousands of Libyans under the Italian colonial regime, and covering the period of military operations of Libya by Axis and Allied Powers during the Second World War involving extensive mine- and booby-trap-laying; treatment of the problem by the United Nations since it was first referred to the General Assembly in 1948 (see e.g. General Assembly resolution No. 529 (V) of 29 January 1952) up to its weakened response in 1987 attributed to lack of information (see General Assembly resolution A/42/514), including its consideration in the context of environmental protection by UNEP's Governing Council (see e.g. UN General Assembly document A/31/210); support for the Libyan initiative at meetings of the Non-aligned Movement, the Islamic Conference, the OAU and the League of Arab States; the applicability of the laws of war to the issues involved; and the relevance to those issues of the work of the International Law Commission on the topic of State responsibility.

43. Under the heading 'General Observations', the Secretariat study concludes, inter alia that there are some developing countries whose economies and national development plans have been crippled by the continued existence of the remnants of war, especially abandoned mines, and that the colonial powers should not evade their accountability under existing international law for dealing with those problems, including their duty to cooperate with the States concerned and responsibility for the provision of technical and financial assistance. The study considers a bilateral approach to be the best means of initiating negotiations with a view to arriving at viable solutions. The study mentions, by way of example, agreements between Libya and Italy (text reproduced in The Great Jamahiriya, 1 September 1989, p. 15), and between the United States of America and Vietnam concluded on 27 January 1973 which includes a Protocol on removal, permanent de-activation or destruction of mines in the territorial waters, ports, harbours and waterways of Vietnam (text reproduced in 12 ILM (1973) 91-93). 
44. The delegate of Libya emphasized the need for recognition of the right of colonized countries to receive compensation from the former colonial powers and urged that the Committee adopt a resolution incorporating the legal principles relevant to the subject. The delegates of the Democratic People's Republic of Korea, Uganda, Palestine, Ghana, Egypt and Sierra Leone acknowledged the importance of the subject and the need for further work on it by the Committee (Report, pp. 174-176).

45. The delegate of Japan, recalling his delegation's intervention at the Committee's Twenty-Ninth session, expressed reservations regarding the subject, indicating that in his view it was of a highly political nature and not appropriate to be dealt with in a multilateral forum like the Committee (Report, p. 176).

46. The observer from Italy, recalling his delegation's intervention at the Committee's Twenty-Ninth session, said that his government rejected the position that any obligation of the type referred to in the discussion could arise on the basis of existing rules of international law (Report, p. 175).

\section{Decision 6 of the Committee}

47. In its decision on this item (Report, p. 113), the Committee, inter alia: $\therefore$

Reaffirms the right to self-determination of countries and peoples under colonial rule;

Further reaffirms the right of all peoples formerly under colonial rule to receive compensation for damage suffered as a result of colonial rule;

Calls on former colonial powers to fully and effectively cooperate with the former colonial people in eliminating the consequences of colonial rule and providing information on those exiled or detained during the colonial era.

Further calls upon the colonial powers to return to their rightful owners the cultural heritage which was illegally plundered and removed by colonial powers;

Requests the Secretary General to continue his detailed study to enable the Committee to take a definitive decision on the matter. ..'12

12. The delegate of Japan expressed reservations with respect to this decision, declaring that the subject was of a highly political nature and was not appropriate to be dealt with in a multilateral forum like AALCC. 


\section{MATTERS OF COMMON CONCERN HAVING LEGAL IMPLICATIONS}

\subsection{Preparation for the United Nations Conference on Environment and Development ${ }^{13}$}

48. The Committee had before it the following three documents prepared by the Secretariat: 'Notes on Major Agenda Items of Working Group III of the Preparatory Committee for the United Nations Conference on Environment and Development ${ }^{\prime 14}$ (Doc. No. AALCC/XXXI/ISLAMABAD/92/1), 'Framework Convention on Climate Change: An Overview' (Doc No. AALCC/XXXI/ISLAMABAD/92/2), and 'Development of a Global Convention on Biodiversity' (Doc. No. AALCC/XXXI/ISLAMABAD/92/3).

49. Document AALCC/XXXI/ISLAMABAD/92/1 contains notes by the AALCC Secretariat on progress in drafting the 'Earth Charter/Rio Declaration' on environment and development by Working Group III of the Prepcom; as well as on a survey of existing agreements and instruments and the further development of international environmental law and on institutional issues.

50. To the note on progress in drafting are attached as annexes a draft proposal submitted to Working Group III of the Prepcom by Ghana on behalf of the Group of 77, entitled 'Principles on General Rights and Obligations', ${ }^{15}$ and a Consolidated Draft of the same title containing proposals received from participating delegations.

51. The AALCC Secretariat's note on the Prepcom's survey of existing agreements and instruments and the further development of international environmental law contains comments and recommendations on the purpose of the survey, the range of agreements and instruments to be covered and the basis for according priority to certain agreements or instruments, the criteria for evaluating the effectiveness of existing agreements and instruments and their overall contribution to sustainable development, and possible areas to be examined in connection with the further development of international environmental law. Annexed to this note is a draft decision for adoption by AALCC on the agenda item as a whole. Subsequently adopted, it is reproduced, in part, in paragraph 75 below.

52. The AALCC Secretariat note on institutional issues, having outlined consideration of the subject by Working Group III of the Prepcom, lists the then-existing proposals before it with regard to institutional mechanisms

13. Cf. 1 AsYIL (1991) 216.

14. Hereinafter: Prepcom.

15. The draft proposal was originally submitted in August-September 1991, and was re-submitted in revised form in March 1992 as UN doc. A/CONF.151/PC/WG.III/L.20/Rev. 1. See below. Selected Documents. 
(part II $)^{16}$ and suggests areas for consideration by Member States when preparing for future sessions of the Prepcom (part III). ${ }^{17}$ These parts of the note are reproduced in full below:

$\therefore$

II. EXISTING PROPOSALS ON INSTITUTIONAL MECHANISMS

Since the beginning of the preparatory process for UNCED, there have been advanced a number of proposals on the institutional mechanisms for the need to integrate environment and development. Most of them have concentrated on the intergovernmental mechanisms. The following is a summary of the main proposals contained in PC/80, which the Prepcom may wish to consider:

- The establishment of a "Sustainable Development Commission" to which all United Nations bodies, agencies and programmes as well as "treaty" Secretariats involved in the area of environment and development would be accountable. It would meet annually and examine policies and programmes for promoting global action on environment and development and would be both a political deliberative body and co-ordinating mechanism for the UN system's activities in this area.

- The establishment of a high-level deliberative body at the political level which would provide a forum for overview and policy co-ordination of environmental issues and their integration with other major issues to which they relate in the security, economic, social, humanitarian and common areas. Some suggest that this be done through establishment of an "Environmental Security Council" or a Committee of the General Assembly, supplemented, perhaps, by a special committee of the Security Council to deal with the issues which are security related. It is also suggested that these functions could be performed according to the Trusteeship Council a new mandate as the forum in which member states exercise their trusteeship for the integrity of the global environment and commons.

- The creation of an "Economic Security Council" composed of around 24 members, representing all groups of member states, as the centrepiece of the "Economic United Nations" parallel and equal to the "Political United Nations". The Council would be supported by an interdisciplinary central Secretariat with a large number of highly qualified experts and a number of smaller sectoral Secretariats maintained at the level of each of the agencies. The Council would bring together the competent ministers, depending on the problems on the agenda, and central Secretariat would be led by a group of independent persons (commissioners).

- The creation of an "International Development Council" within the United Nations to meet for a high-level forum for member states to discuss development issues and give overall policy guidance for $\mathrm{UN}$ operational activities for development.

- The revitalization of the Economic and Social Council. It is suggested that, in principle, most of the functions envisaged for the proposed new inter-governmental mechanisms referred to above could be undertaken by ECOSOC. In order to do so there would have to be a very significant improvement in its credibilities and strengthening of its effectiveness. The subject of restructuring and revitalization of ECOSOC is now on the agenda of the General Assembly.

- The convening of a world Summit on Global Governance similar to the meeting in San Francisco and at Bretton Woods in the 1940s. To prepare the ground for such a Summit, it was suggested to establish an independent international commission

16. AALCC/XXXI/ISLAMABAD/92/1 pp. 25-28.

17. Ibid. 29-38. 
on global governance, composed of individuals functioning in their personal capacities.

In addition to the above-mentioned proposals, there are a number of proposals related to the constructive changes of the Secretariat of the United Nations itself and those of its agencies and programmes. The report of the World Commission on Environment and Development, "Our Common Future", points to the need for a high-level centre of leadership for the United Nations system as a whole with capacity to assess, advise, assist and report on progress made and needed for sustainable development. That leadership should be provided by Secretary General of the United Nations . . . who should constitute under his chairmanship a special United Nations Board for sustainable Development. The principal function of the Board would be to agree on continued tasks to be undertaken by the agencies to deal effectively with many critical issues of sustainable development that cut across agency and national boundaries. In this context proposals have also been made for the revitalization of the Environmental Co-ordinating Board.

During the last August Session, a few more concrete proposals were brought out, and attracted the attention of many delegations. They called for the institutional adjustments, including:

- A possible combination of existing ECOSOC Committees into a single intergovernmental Committee to deal in a comprehensive way with the more political aspects of environment and development;

- An annual joint (or combined) UNDP-UNEP Session on Environment and development as part of the UNDP Council's agenda;

- A high-level effective coordinating mechanism for UN and related agencies and programmes, co-chaired by the UNDP Administrator and the UNEP Executive Director;

- Regionally and nationally focused efforts built around or based on the existing UNDP Round table/World Bank Consultative Group of donors and UN agencies.

Quite a few proposals focused on the strengthening of the UNEP, which inter alia suggested:

- that UNEP be strengthened in its own right as the Central agency in the UN system on matters of environment and development. Its operations should be strengthened and enhanced by provision of additional funds, recruitment of experts and improvement of its infrastructural arrangements;

- that an interagency linkage be strengthened through the creation of coordinational offices at the UNEP Headquarters for all UN agencies;

- that the membership of the Governing Council be increased to make it more representative at the decision-making level in accordance with UNEP's new status;

- that UNEP's role be strengthened in coordinating regional environmental centres to enable them respond to issues of development both in the developed and developing countries;

- that a mechanism for the prevention and peaceful settlement of ecological disputes be established under UNEP and be located at its headquarters.

Deliberation on the subject continues. All the proposals mentioned above however need to be carefully examined. 


\section{PREPARATION FOR THE AALCC's COMMON STAND}

1. Dimensions and Emphasis of the Issue

As stipulated by the Statute of the AALCC, one of the main purposes of the Committee is to exchange views and information on matters of common concerns having legal implications and to make recommendations thereto if deemed necessary. The Committee may, therefore, wish to consider this subject item of institutions related to UNCED, which is on the agenda for Working Group III of the Prepcom, and to make efforts to form a common stand thereon. This would render valuable assistance to its member governments in preparing for the UNCED at its final stage.

It is the suggestion of the Secretariat that general dimensions and the emphasis in the Committee's consideration of this item would be placed on the following substantive aspects which seem to be the key elements for the complex institutional issues:

(a) Basic principles and guidelines to be applied to deal with the institutional mechanisms arising from the need to integrate environment and development;

(b) Framework of intergovernmental mechanism for political deliberation and policy guidance in the field of environment and development;

(c) Framework of interagency coordinating mechanisms within the United Nations System; and

(d) Other major institutional arrangements such as strengthening of UNEP and settlement of ecological disputes.

\section{Basic Principles and Guidelines on Institutions}

It should be recalled that the General Assembly, at its resumed 45th Session, adopted Resolution 45/264 on the subject of restructuring and revitalization of the United Nations in the economiic, social and related fields. The Resolution contains 7 basic principles and guidelines for action. They are:

(a) restructuring is primarily the responsibility of member states;

(b) political will is an essential prerequisite for reform;

(c) the exercise should aim at achieving greater complementarity between the bodies and organs of the United Nations with the General Assembly;

(d) the preservation of the "democratic principles" in the decision-making process of the United Nations;

(e) the need to preserve and strengthen transparency and openness;

(f) the most efficient and effective use of the financial and human resources of the United Nations system in the economic, social and related fields; and

(g) importance of the ongoing revitalization of ECOSOC.

We are convinced that the above principles and guidelines are of direct relevance to UNCED. They could be applied not only to the restructuring and revitalization of ECOSOC but also equally to the institutional arrangements of UNCED. AALCC may thus wish to request the Prepcom to comply with these principles and guidelines in considering the institutional issues related to the UNCED.

In the context of the Sixth principle on efficient use of financial and human resources as mentioned above, we further suggest that the Prepcom should ensure that no proliferation of new institutions will take place. First of all it should concentrate on the improvement and strengthening of existing institutional mechanisms in the United Nations system, and on enhancing their better cooperation and coordination. We therefore stand firmly by the idea that no new intergovernmental bodies should be set up, except by combining or transferring resources from existing bodies. It would be the most logical and efficient way to meet the need for the institutions by making full use of the existing financial and human resources. 
Based on the above-mentioned guidelines, the AALCC may wish to call attention to ECOSOC and UNEP.

At a high level, without prejudice to the jurisdiction of the General Assembly, the focus could be on the restructuring and revitalization of ECOSOC so that it may be enabled to serve as an intergovernmental forum in the field of environment and development, and under the authority of the General Assembly, to play a central role in policy-deliberation. It is true that most if not all of the functions so far envisaged for the proposed new intergovernmental mechanisms referred to above are within the scope of ECOSOC, and could be undertaken by it if the necessary restructuring would be completed. So the importance of ECOSOC in the context of the UNCED should be underscored.

With regard to UNEP, as pointed out in para 7, pc/809 it is widely recognized that an important result of UNCED is expected to be substantial strengthening of the mandate and capacity of the UNEP, which is mandated to be the coordinator of the environmental activities of the United Nations system. The Secretariat of the AALCC is of the view that the building of a better coordinating mechanism in the field of environment and development should take the UNEP as its core, and such mechanism should be designed on the basis of strengthening UNEP. In principle, UNEP should play a central role in overseeing the implementation of Agenda 21 and in coordinating the various activities of UN system as a whole in the field of environment and development.

\section{The Framework of Intergovernmental Mechanism}

The framework of intergovernmental political deliberative mechanism could be constituted in a two-fold process.

At the primary level, the General Assembly, which has the broadest membership of States and to which ECOSOC, UNEP, UNDP and other parts of the United Nations system report, should remain in charge of overviewing global action in the dimension of sustainable development as suggested in Resolution XX/228's description of the General Assembly as the appropriate political forum for discussion of international environmental policy. It is also the appropriate body where new global initiatives can be taken. For this purpose the principal function of the General Assembly in the political deliberation and policy guidance related to environment and development should be further enhanced and reinforced. In this context we suggest that a main Committee of the General Assembly be designated to be responsible.

Various ideas have been raised with regard to a further strengthening of intergovernmental cooperation at the highest level. It has been suggested that a regular high-level meeting, preferably at the Ministerial level, be instituted, which would give general policy guidance to the implementation of the objectives and action proposals of the UNCED and which would consider possible gaps. In our opinion, it is not necessary to create such a regular meeting at Ministerial level. It is better to leave the matter of a ministerial meeting to the discretion of the General Assembly in light of the importance of the issues to be dealt with and the feasibility of convening such a meeting.

Under the General Assembly, a forum for more focussed deliberation may also be needed. That is to be the second level process. ECOSOC which is able to devote in depth discussion to the thematic issues, and in which most of the time environment and development aspects play a dominant role could be considered in this context. One idea that has been suggested is that a number of existing Committees of ECOSOC dealing closely with related matters could be combined into a more comprehensive Committee to deal with environment and development. Reference could be made in this regard to the Committee on New and Renewable Sources of Energy, the Committee on National Resources and the Committee on Science and Technology 
for Development. The task of monitoring and reviewing the implementation of UNCED's results, including Agenda 21, could be entrusted to this Committee. We consider the idea a positive one. We also underscore the importance of wider involvement and participation of the developing countries, and the democratic principle of decision-making in the proposed Committee. The proposed combined Committee could have the title of "The Commission/Board on Sustainable Development".

Furthermore, to facilitate the deliberation of the more technical aspects of environment and development, a special advisory group could be established under the direction and supervision of the proposed "Commission on Sustainable Development". The advisory group would be composed of a number of individual experts, mainly drawn from the human resources of UNEP and UNDP, the main tasks of which would be to consider, from the technical perspective, the questions referred to it by ECOSOC and its responsible Committee, and make recommendations thereto, as appropriate.

In short, the basic framework of the intergovernmental mechanism would be formed with a two fold structure. At the first level, the General Assembly itself and one of its main Committees as well as a possible irregular higher-level meeting at the ministerial level are envisaged. At the second level, ECOSOC in general, the "Commission on Sustainable Development" a new more comprehensive intergovernmental Committee which would be a restructured combination of several existing Committees of ECOSOC, in particular, and a subordinate advisory experts group would serve as the Centre for the regular intergovernmental policy deliberation in the field of environment and development, and for overseeing the implementation of Agenda 21.

\section{The Framework of the Interagency Coordinating Mechanism}

To establish a more effective and efficient interagency coordinating mechanism in the field of environment and development is undoubtedly crucial in the implementation of Agenda 21 and other outcomes of UNCED.

In keeping with the guidelines mentioned earlier, the Secretariat of the AALCC should like to make the following proposals:

(a) The coordinating mechanism should cover not only UNEP and UNDP but also other relevant agencies or programmes involved in the environment and development; namely, all the related activities within the United Nations system.

(b) The coordinating mechanism should be formed with the UNEP as its core making full use of its facilities and expertise.

(c) A steering interagency Coordinating Committee might be created under the chairmanship of the UNEP's Executive Director, who should have the rank of Under Secretary General of the United Nations, or under the co-chairmanship of the Chiefs of UNEP and UNDP, or other appropriate joint management arrangement. The Committee would be composed of the responsible high ranking officers from UNEP, UNDP, the Secretariat of UN, the World Bank and other UN bodies involved in the area of environment and development.

(d) The Coordinating Committee would be most appropriately located in the headquarters of UNEP so that UNEP's facilities and expertise would be fully used. Thus UNEP itself would play a real central role in effectively coordinating the various activities related to environment and development within the United Nations system.

(e) The Coordinating Committee would have close ties with the Administrative Committee on Coordination (ACC) of the UN Secretariat, which is chaired by the Secretary General and is currently responsible for coordination of environmental and developmental activities in the UN system. Thus a better cooperation and coordination could be created and maintained between the Secretariat and its agencies concerned in the field of environment and development. 
(f) With regard to the relationship of the Coordinating Committee and the "Commission/Board on Sustainable Development", the former should function under the supervision of the latter, through which it would report on its work.

\section{Other Major Institutional Mechanisms}

In addition to the intergovernmental political deliberative mechanism and the interagency coordinating mechanism, certain institutional arrangements may be necessary to substantially strengthen UNEP in the field of peaceful settlement of international ecological disputes.

That UNEP should be further strengthened as the central catalyzing, coordinating and stimulating body in the field of environment within the United Nations system has been widely recognized. Now the question is how to achieve the goal. A number of ideas and proposals have been suggested. It is the view of the AALCC Secretariat that in this regard, the following key elements should be primarily addressed.

(a) The mandate of UNEP, as contained in Resolution 2997, should be reaffirmed in the context of UNCED and the need to integrate environment and development. The strengthening of UNEP first refers to strengthening its mandate, purposes and functions. In this respect, we suggest that the mandate of UNEP in the areas of further development of international environmental law, coordinating activities related to environment and development within the UN system and the settlement of international ecological disputes and overseeing the implementation of Agenda 21. These and other responsibilities emanating from UNCED might be strengthened or added.

(b) The leadership of UNEP. To ensure a wider participation of the developing countries, which is crucial to the performance of UNEP's mandate as enhanced in a satisfactory way, the Governing Council of UNEP should be enlarged and its memberships increased so as to make it more representational at the decisionmaking level. The new memberships should be allocated on the geographical basis, taking into account the special needs of the developing countries. We also think that rank of the Executive Director of UNEP should be at the status of the Under Secretary General of the United Nations.

(c) The Financial Basis. To enable UNEP to carry out its expanding mandate and responsibilities, it is requisite to call for the strengthening of its financial basis. This goal could be attained by enlarging its budget and opening up other additional financial resources besides voluntary contributions.

(d) The Coordinating Mechanism. To ensure that UNEP is capable of taking the responsibility for coordinating environmental activities within the United Nations system, a more effective and efficient coordinating mechanism should be established, the framework of which has been outlined above.

(e) The capacity of UNEP. Besides above elements, the improvement of UNEP's infrastructure and enhancement of its expertise should be addressed. We agree with the suggestion that UNEP needs greater expertise with respect to the developmental side of environmental questions, so that right from the outset environmental and developmental aspects of an issue could be fully considered.

We do believe that the strengthening of both the human and material resources of UNEP would make it better able to assume the responsibilities UNCED might entrust to it.

With regard to peaceful settlement of international environmental disputes, while we consider a more and effective use of the International Court of Justice, the Permanent Court of Arbitration and other international arbitrational institutions very important, it is also worthy envisaging a possible special environmental tribunal within the mandate of UNEP or the Commission on Sustainable Development." 
53. Document No. AALCC/XXXI/ISLAMABAD/92/2 deals with the Intergovernmental Negotiating Committee (INC) established by General Assembly resolution 43/53 of 6 December 1988 and entrusted with the task of preparing an effective 'Framework Convention on Climate Change' and any other related agreements as might be agreed upon. The document recalls the guidelines for negotiations, and the mandates of Working Group I (commitments on limiting and reducing net emissions of greenhouse gases, and related matters) and Working Group II (Legal and institutional mechanisms) as reflected in the Report of the INC's first session (A/AC.237/ 6 ), and outlines the progress of the work up to and including the negotiations which took place at the INC's Third Session, held at Nairobi 9-20 September 1991.

54. Comments by the Secretariat on the negotiations thus far, include the following:

$\therefore$

7. It may be recalled that during the INC Second Session in Geneva, the Bureau of the Conference prepared a document which set out a compilation of 110 Principles compiled on the basis of informal and non-papers and the views expressed by various delegations during the Geneva Session. The Bureau was further requested to prepare a consolidated compilation of Principles. Accordingly, the Bureau submitted two documents namely, A/Ac.237/Misc 6 and A/Ac.237/Misc 9. The document A/ Ac.237/Misc 6 containing compilation of texts related to principles arranged under five main headings and a number of subgroups. A/Ac.237/Misc 9 contained a more condensed set of Principles.

8. Working Group I took both these documents as the basis for discussion. During the discussion, there were divergent views on the purpose of inclusion of the Principles in the text of the Framework Convention. It was argued that many of these Principles could be accommodated in the Preamble and in the Section on commitments. On the other hand, while emphasising the need to include a set of Principles, it was felt that a section dealing with basic Principles would strengthen the commitments and lay the guidelines to implement those commitments.

9. Although there are divergent views in regard to the utility of inclusion of Principles in the text of the Framework Convention, it appears that ultimately an agreement might be reached to that end, and a section containing a short list of basic principles will find a place in the Convention. It should be pointed out that there are precedents where similar Conventions have incorporated a section on Principles. Besides, the Earth Charter under consideration in the UNCED and the draft text of the Framework Convention on Bio-diversity also contemplate inclusion of a section on Principles. Such a section in our view should be in the body of the Convention rather than in the preamble.

10. The Revised Conference Room Paper (A/Ac.237/WG1/Rev.1), prepared by the co-chairs of Working Group I in the light of the two rounds of discussions held during the Nairobi Session of the INC, contains a long list of Principles. Endeavour should be made to identify the principles which command wide support keeping in view their legal nature. Since "environment" in general and the climate change in particular, are evolving concepts embracing many scientific and technical matters, care ought to be taken when identifying such principles to ensured fairness and their linkage to climate related issues. 
11. A tentative list might include such principles as common concern of mankind, sovereignty, equity, common but differentiated responsibility, right to development, sustainable development, Precautionary Principles, Polluter pays Principle, Nonconditionality, special circumstances, comprehensiveness, liability and flexibility. There is a possibility that the inclusion of some of these principles might be the bone of contention or an agreement might be reached to elevate some as commitments and general principles. That would help shorten the list. While streamlining the texts of the agreed principles, it would be desirable to use precise legal language. The Declaration of the Second World Climate Conference may provide useful guidance in that context.

12. Section on "Commitments" will form the fundamental Part of the Framework Convention. Indeed, the success or failure of the negotiations on the Framework Convention will largely depend upon how the issues related to commitments will be tackled during the forthcoming INC Session in Geneva and the subsequent one in New York. In spite of extensive and intensive discussions during the last two INC Sessions divergent views could not be narrowed down.

13. It is generally agreed that the Framework Convention should stipulate two types of commitments, namely (i) general commitments and (ii) specific commitments. The general commitments should be undertaken by all the Parties to the Convention whether they are developed or the developing states. The specific commitments could oblige a group of countries, particularly the industrialised countries.

14. It is evident from the trend of the discussions in Geneva and Nairobi Sessions that it would be difficult to draw a line between the two types of commitments. There may be areas where the obligations evisaged within the general commitments would spill over to specific commitments. There is likelihood that if the specific commitments are framed in a diluted form, they could take the shape of general commitments. In the course of the discussions, interesting concepts such as "common but differentiated responsibility" and a third category of commitments termed "unilateral commitments" have been introduced. These concepts need to be examined in detail. They appear to be simple but translating them into specific legal language and the subsequent implementation of the obligations envisaged in that context, would have implications which may go well beyond the imagination at this juncture of negotiations.

15. The text on commitments submitted by the Bureau of Working Group I prior to the conclusion of the Nairobi Session is very elaborate. Section II contains a set of eighteen paragraphs with several alternative formulations for most of the paragraphs. Among other things, these commitments envisage immediate and significant emission reductions, energy conservation, rational use of energy and development, promotion of co-operation by means of systematic observations, research and information exchange. Section III dealing with differentiation of commitments draws a distinction between the developed and developing countries mainly on the basis of economic criteria. Section IV is concerned with specific commitments in respect of all sources and sinks, including preparation of national strategies and programmes.

16. During the discussion, while there were different views on many of these commitments, it was generally recognised that all such commitments should be realistic and strike a balance between environment and economic development. The target and time-table for emission reduction should be flexible. With regard to sinks, it was stressed that while dealing with the question of forests, the relevant measures should take into account the ongoing deliberations in the UNCED. It was also pointed out that since oceans play an important role in the Earth Climate System, their significance as sinks needs to be examined. It was recognised that as the indirect consequences of the measures would vary, there was the need to consider "special situations" and the 
degree of vulnerability. The examples of the countries whose economy depended upon the production and exportation of fossil fuels and those countries which were not in a position to find substitutes for fossil fuels were particularly relevant. On the question of the preparation of national strategies and programmes concern was expressed particularly by the developing countries. On the other hand it was emphasised by the developed countries that the availability of the financial and technological resources was closely linked to the commitments to be undertaken by the developing States.

17. The commitments on technology co-operation and transfer are crucial elements of the Convention. The General Assembly resolution 44/228 laid the guidelines for establishing an effective technology transfer mechanism. Further, INC decision 1/1 provided that such mechanism should be an integral part of the framework convention. During the last two INC Sessions, Working Group I held discussions on the commitment relating to transfer of technology and its mechanism as discussed in Working Group II. Divergent views on both the issues among the developed and the developing countries appear to be a great stumbling block. It has been suggested that the issues relating to technology transfer should be viewed in a broader perspective and should include technical co-operation as well. Such a notion would promote a "shared partnership" between the developed and developing countries. No doubt, this is an ideal suggestion. However, the "ifs" and "buts" associated with this ideal cannot be overlooked. The developing countries need support to develop their technological base and the "best available" "state of-art technology" which should be cost effective and environmentally safe and sound. Their primary need is "soft technology" to build up their own capabilities for climate monitoring and assessment. The framework convention must ensure expeditious transfer of the relevant technology on a fair and most favourable conditions. How far such terms will be "non-commercial" would depend on the source. Also, consideration might be given to the issues related to Intellectual Property Rights. The UNCED and the INC on Biodiversity are also engaged in similar discussion. It would be desirable to bring the INC discussion on the framework convention on climate change on similar lines.

18. A proposal has been made for the formation of a study group on technology transfer. It would be desirable to constitute such a group during the forthcoming INC Session in Geneva. The Study Group could identify the basic issues and suggest modalities for suitable mechanism on this matter.

19. Issues concerning commitments and Institutional Mechanisms for the provision of adequate and additional financial resources to enable developing countries to meet incremental costs required to fulfil the commitments evisaged in the Convention are of crucial importance. During the INC Second and Third Sessions, discussions on these matters have shown a great divergence of views. Some of the developed countries have expressed general support. However there is no explicit commitment in this regard.

20. The first and the foremost consideration therefore would be to identify ways and means to provide new and additional financial resources as it has been realised that the existing financial resources available from the United Nations Systems and other regional and bilateral arrangements would not be adequate. Suggestions have been made for the establishment of a funding mechanism for the purposes of providing financial and technical co-operation, including the transfer of technologies to the developing countries parties. Such a mechanism would include a multilateral fund composed of adequate additional and timely financial resources apart from other means or arrangements of multilateral, regional and bilateral co-operation. 
21. Another proposal provides for the establishment of a Climate Fund which would operate under the authority and guidance of the Parties to the Convention. It envisages establishment of an Executive Committee consisting of members selected on the basis of an equitable representation of the developed and developing countries parties to the Convention. Further, the Climate Fund would be financed by contributions from developed countries parties on a grant basis, and according to criteria to be agreed upon by the Parties. Its function should be to meet the costs for developing countries parties to adapt and mitigate the adverse effects of climate change and the development and transfer of technology and knowledge relevant to scientific and technical research. Finally the fund would also meet the expenses concerning the Secretarial services and related support costs of the Climate Fund.

22. Another interesting proposal provides for the establishment of a clearing house system based on a bilateral agreement between countries and regional agreement between several countries. Accordingly, a clearing house would appraise and select projects for reducing emissions, according to their cost-effectiveness and co-ordinate the funding of these projects. The net reduction in emissions resulting from any specific project would be created to the country that contributes to the funding of the project and deducted from its national commitments. Thus, the transfer of financial resources between countries would be integrated in the system and would also facilitate co-ordination with other financial mechanisms. Another suggestion is that the recent initiative jointly undertaken by the World Bank, UNEP and the UNDP in establishing the Global Environment Facility (GEF) provides an innovative financing mechanism to help developing countries to meet their financing requirements to an extent.

23. During the discussions at the Nairobi Session, broadly two sets of views emerged and they represented the different viewpoints of the developing and the developed states on the financial mechanism to be incorporated in the framework convention on climate change. The developing countries insisted on the establishment of an independent fund democratically operated under the guidance and supervision of the Conference of the parties. As for the sources constituting the fund, it was stressed that adequate new and additional financial resources should be provided to the developing countries to meet their obligations as envisaged in the Convention.

The developed countries, on the other hand considered that the GEF operated by the World Bank, UNDP and UNEP would provide the suitable mechanism. The GEF was a three year pilot programme which could be improved both in terms of augmenting its resources and governance structure by enhancing the role of developing countries in its decision making. There was agreement to commit adequate and additional financial resources to enable developing countries to meet incremental cost required to fulfil their commitment. However, views differed on whether it should be "full" or "agreed" incremental cost. It was stressed that the concept needs to be defined in a clear and comprehensive manner.

24. Suggestions were made to examine the concept of an insurance scheme and "Polluter Pays Principle" taking into account relevant precedents and the development of international law in these areas.

25. Working Group II has been discussing issues related to legal and institutional mechanism, including, inter alia, entry into force, withdrawal, compliance and assessment and review. With regard to scientific assessment and exchange of information there are fairly convergent views. A suggestion was made for the establishment of a Scientific Committee. In that connection, it may be pointed out that the basic foundation of the framework Convention is the scientific assessment of the factors related to climate change. The Intergovernmental Panel on Climate Change 
(IPCC) which was established in 1988 jointly by the WMO and the UNEP has provided valuable guidance and support to the work of the INC. This fact was also recognised by the General Assembly when it constituted the Intergovernmental negotiating Committee for the Framework Convention on Climate Change. It is not yet clear what role the IPCC would play after the completion of the work of the Framework Convention. It is however generally felt that till the Framework Convention comes into force, there will be need for assistance from the IPCC. Irrespective of such transitional arrangements, the need for a Permanent Scientific organ cannot be over-emphasised.

26. Consideration should also be given for the establishment of a specialised body like GESAMP, which is an advisory body consisting of specialized experts nominated by the sponsoring agencies (IMO, FAO, UNESCO, WMO, WHOM, IAEA, UN, UNEP) which provides authentic scientific advice on marine pollution problems. Perhaps IPCC could be made more broad based and could be thought of assuming such a task. In both cases, the structure, role and function of the two bodies would have to be considered in detail.

27. Preliminary discussions on verification and compliance indicate the sensitive nature of the issues involved. While there is a clear understanding that the thread of common but differentiated responsibility should run through various commitments envisaged in the Framework Convention on Climate Change, there are divergent views with regard to the achievement of this objective. The over-emphasis on compliance mechanisms may delay and perhaps defeat the very purpose for which such a mechanism is being advocated. The commitment to establish a national reporting system, submission of periodic national reports, subsequent review by a supranational authority and sanctions for any infringement of the commitments, all viewed together pose problems of many and different kinds. The lack of infra-structure to prepare the national inventory and collation of relevant information would deter the developing countries to undertake the commitment to make a report at regular intervals. What would be the worth of the national report, if there is no substantive information to present? Would it not be a cause for complaint? This may sound negative but certainly not illogical.

29. Views have been expressed outlining the compliance procedure and ways to deal with the complaints. Suggestions have been made that recourse should be considered to refer the disputes to the International Court of Justice or to an Arbitration Tribunal. Non-resolution of a complaint would not necessarily give birth to a dispute for which recourse ought to be made compulsorily to the highest judicial organ. Any compulsive dispute settlement procedure has remained an idealistic goal for long. The Framework Convention on Climate Change is not the kind of international instrument where such an idea could be translated into action. There is some gap in establishing the scientific credibility of the climate change convention. It would be far from reality to think of filling that gap with legal firmness. The 1985 Vienna Convention on the Protection of the Ozone Layer follows a practical step by step approach in regard to the matters concerning dispute settlement. Consideration may be given to incorporating a similar provision in the text of the Framework Convention on Climate Change. It would save time and close the discussion on a crucial issue.

30. The question of submission of national reports and their review would also need to be considered in a more flexible way, particularly in the context of the developing countries. The cart cannot be put before the horse. It is encouraging to note that there is great enthusiasm to support the developing countries in the preparation of country-studies and the creation of necessary national infrastructure which would 
enable them to undertake any commitment to this effect. A suggestion has been made that as an alternative to "Pledge and Review" unilateral commitment could be undertaken by the parties to the Convention. The intention to chase out the twin ghosts which haunted the Nairobi meeting from its very first day is laudable. However, one cannot rule out the possibility that the ghosts might enter Geneva in a different shape.

31. It has been suggested that apart from the general and specific commitments or obligations, the Convention could envisage a legal framework for States to assume unilateral obligations. Such unilateral obligations would be "additional" and could be related to the availability of financial and technical assistance particularly for those developing countries which are not in a position to fully implement unilateral commitments without such assistance. Although it has not been stated categorically, it is amply clear that such financial and technical assistance could be given preferably to those countries which are prepared to undertake "unilateral" commitments to prepare and submit national reports which will be subject to review by an international review body.

32. It may be a little premature to make any specific comments on the concept of unilateral commitments at this juncture. However, at least two general observations may not be out of place. First, it has been noticed that during the discussions on the commitment with regard to the financial and technical resources, developed countries have zealously conveyed their hesitancy in making any specific commitments. It would be interesting to note if they will be prepared to make any express unilateral commitments in that respect. Secondly, the developing countries, indeed the Group of 77 as a whole, have made it very clear, leaving no ambiguity, that their national strategy could not be the subject of review by an international body. The fear of the twin ghosts entering the Conference room in Geneva from the backdoor is not imaginary but real. Maybe, on the eve of Christmas, an Angel enters from the front door and saves the Geneva Session from the impending deadlock on this issue. ${ }^{18}$

55. Document No. AALCC/XXXI/ISLAMABAD/92/3 deals with the Intergovernmental Negotiating Committee (INC) for a Convention on Biological Diversity constituted by decision 16/42 of the Governing Council of UNEP in continuation of work on negotiation of an international legal instrument on the subject, previously undertaken by a succession of expert groups. The document recalls the mandates of Working Group I (fundamental principles, general obligations, implementation measures) and Working Group II (issues relating to international co-operation, technology and science, financial needs and mechanisms, and genetic material), and outlines the progress of work up to and including the negotiations which took place at the INC's Fourth Negotiating Session, held at Nairobi from 23 September to 2 October 1991.

56. The Secretariat provides 'An overview of the draft Convention' in part III of the document, ${ }^{19}$ as follows:

18. AALCC/XXXI/ISLAMABAD/92/2 pp. 15-25.

19. AALCC/XXXI/ISLAMABAD/92/3 pp. 11-21. 
$\therefore$

\section{AN OVERVIEW OF THE DRAFT CONVENTION}

21. The conservation of biological diversity and the problems relating to climate change are among the most important environmental issues facing the world at the present juncture. The destruction of habitats is causing thousands of species to become extinct every year and the consequent loss of biological diversity is a main factor in what might become an irreversible climate change. Biological diversity, therefore, needs to be conserved so that mankind could derive maximum sustainable benefit from world genetic resources.

22. The international community has already enacted instruments to protect biological diversity but they have proved to be inadequate. It is, therefore, essential to supplement such action by a global Convention which would enable the present generation to discharge its responsibility to future ones through preserving their heritage.

23. The Draft Convention on Biological Diversity presently under negotiation under the UNEP's auspices is intended to evolve a broad legal framework pulling together a wide range of actions at national and international levels for conservation and sound use of biological diversity that has hitherto been taken on a piecemeal basis. The Draft Convention originally consisted of 41 articles, but during the course of the ongoing intergovernmental negotiations six additional articles have been incorporated in the text, namely, Article 5 Bis, Article 7 Bis, Article 14 Bis, Article 15 Bis, 17 Bis, and 23 Bis.

24. Article 1 is addressed to setting forth the objectives of the proposed Convention. Although it has been considerably shortened, it stays within brackets in Article 2 on Use of Terms and is intended to be elaborated at a later stage. Article 3 is purported to enshrine the basic principles that would underpin this legal instrument. The basic principles recognized are that obligations should include in-situ and ex-situ conservation, intergenerational equity and responsibility, arrangements for the transfer of technologies, including biotechnology, and the establishment of financial mechanisms.

25. Article 4 is intended to frame the general obligations of the Contracting Parties at national and international levels. Article 5 obligates the Contracting Parties to develop their national strategies, plans and programmes for conservation and sustainable use of their biological diversity. Article 5 Bis. on Identification and Monitoring was introduced at the recently concluded fourth session of the INC and it requires the Contracting Parties to identify components of biodiversity important for conservation. Article 6 obligates the Contracting Parties to conserve their biological resources through in situ conservation. Article 7 requires Contracting Parties to adopt individually or jointly policies and programmes for conservation of species exsitu, particularly those which are endangered or of established medical, agricultural or other economic value, relatives of domesticated species and other important sources of genetic material.

26. Article 7 Bis was introduced at the recently concluded fourth session of the INC and it makes compliance by developing Contracting Parties with the obligations contained in Articles 5,6 and 7 conditional upon the provision of technical and financial assistance. Article 8 requires the Contracting Parties to integrate conservation of their biological resources into their domestic decision-making, both governmental and private. Article 9 enjoins the Contracting Parties to establish research and training programmes for the identification, conservation, management and sustainable use and development of biodiversity and its components. 
27. Article 10 requires the Contracting Parties to promote general awareness about the importance of biodiversity and its sustainable use. Article 11 obligates the Contracting Parties to monitor environment impact assessment of their proposed projects or programmes within or beyond the limits of their national jurisdiction. Article 12 requires the Contracting Parties to maintain inventories of biodiversity within their jurisdiction and to establish data banks of such inventories in cooperation with other Contracting Parties and international organisations. Article 13 enjoins the Conference of Parties, the apex body to administer the Convention, to publish a global list of biogeographic areas of particular importance for biodiversity conservation and a global list of species threatened with extinction on a global level.

28. Articles 14 to 19 constitute the backbone of this Convention. Article 14 on Access to (Biological Diversity) (Genetic Material) provides two alternatives. The first one requires each Contracting Party to provide on mutually agreed terms and subject to the provisions of this article, access to in-situ and ex-situ genetic material within its national jurisdiction for purposes of research and development for the collective benefit of mankind. The second alternative makes such access available only in accordance with the Protocols that may be adopted by the Conference of the Parties or bilateral or multilateral agreements in cooperation with relevant research institutions.

29. Article 14 Bis was proposed at the recently concluded INC Meeting in Nairobi and is aimed at protecting the traditional, indigenous and local knowledge that contributes to conservation and sustainable use of biodiversity.

30. Article 15 on Access to Technology requires the Contracting Parties to provide on mutually agreed terms access to relevant technologies inclusive of biotechnology and to eliminate or refrain from imposing restrictions (such as patents or other intellectual property rights) that run counter to the principles enshrined in the Convention. It also obligates the Contracting Parties to encourage the private sector within their jurisdiction to facilitate such access and joint development of technologies by both governmental institutions and the private sector in developing countries. However, paragraph 4 of this article has two alternatives, one overriding the intellectual property rights and the other maintaining the status quo in regard to the existing intellectual property regimes. Article $15 \mathrm{Bis}$, which is closely connected with both Articles 15 and 16, enjoins the Contracting Parties to ensure continuing exchange of information and specialized knowledge and to establish the necessary modalities therefor.

31. Article 16 on Transfer of Technology is more or less along the same lines as Article 15 except for substituting references to access to technology by references to transfer of technology. It obligated the Contracting Parties, in particular the developed ones. to transfer technologies to developing Contracting Parties on a [fair, equitable and (most) favourable] [preferential and non-commercial] basis. Further, in the case of those developing countries that provide the genetic material or are countries of origin of the genetic material, it requires the developed Contracting Parties to transfer biotechnology to them on mutually agreed terms. Furthermore, the developed Contracting Parties are enjoined to (encourage) (ensure) the private sector to transfer technologies to developing Contracting Parties on a [fair, equitable and (most) favourable] [preferential and non-commercial] basis. Two options exist for such transfers - one without any regard to patent regimes and the other having due regard for such regimes.

32. Article 17 on Technical and Scientific Cooperation obligates the Contracting Parties to promote such cooperation in the context of conservation of biodiversity. In particular, it enjoins the developed Contracting Parties to promote such cooperation with the developing Contracting Parties and to provide financial resources for this purpose. 
33. Article 17 Bis on Handling of Biotechnology and Distribution of Its Benefits requires the Contracting Parties to exempt the developing Contracting Parties which are countries of origin of genetic material or providers of genetic material for research, from royalties on patents relating to the products of such research. The developed Contracting Parties are also required to establish mechanisms to invite the participation of developing Contracting Parties in biotechnological research, particularly in relation to the products obtained from species in areas within the jurisdiction of the latter.

34. Articles 18 and 19 are key provisions on funds and funding mechanisms. Article 18 requires the Contracting Parties to provide financial support for conservation of biodiversity which would have to be made available according to the criteria to be decided upon by the Contracting Parties (inter alia on the basis of country studies). It makes amply clear that compliance by the developing Contracting Parties with the obligations stipulated by the Convention would depend on the provision of adequate, new and additional financial resources and technology transfer by the developed Contracting Parties. Article 19 contemplates the establishment of financial mechanisms to extend financial support to the developing Contracting Parties to enable them to comply with the obligations established by the Convention. These include (i) the establishment of a multilateral trust fund and (ii) cooperative arrangements with existing bilateral and multilateral sources of funding. The establishment of these financial facilities is to be decided by the Conference of the Parties at their first meeting or by means of a special protocol to this Convention.

35. Article 20 on International Cooperation requires the Contracting Parties to cooperate with each other and with or through competent international organisations for coordination of their activities and assisting each other in fulfilling their obligations under the Convention. This provision in all probability would be included in Article 4 on General Obligations.

36. Article 21 deals with the relationship of this Convention with other International Conventions relating to conservation of biodiversity. Article 22 enjoins the Contracting Parties, inter alia, to designate national bodies to implement the provisions of the Convention and to coordinate national activities related to conservation measures.

37. Articles 23 to 33 deal with the institutional measures for the Convention itself. They contemplate the establishment of a Conference of the Parties as the apex body to administer the Convention with the help of a Scientific Committee and a Secretariat. Articles 34 to 41 are in the nature of Final Provisions dealing with signature, ratification, acceptance or approval; accession; entry into force; reservations; withdrawals; depositary; and authentic texts.

38. Out of the 47 draft articles (41 plus additional six articles), the four rounds of intergovernmental negotiations have so far been able to give a first reading to Articles 1, 3, 4 and 15 Bis and a second reading to Articles 5, 6, 15,16 and 17. Articles 3 and 4 were expected to be taken up for a second reading at the fourth session of the INC, but their consideration has been deferred until after the Working Group II has completed its deliberations on the articles assigned to it as several of the basic principles and general obligations contained in Articles 3 and 4 are closely connected with negotiations in that Group. Moreover, even in the draft articles given a second reading, there are still options and square brackets to be resolved. Consequently considerable part of the Draft Convention remains to be tackled by the negotiators. These are Articles 2, $5 \mathrm{Bis}, 7$ to 13 and 18 to 41 . They cover definitions of terms used in the Convention; identification and monitoring, ex-situ conservation; research and training; education and public awareness; environmental impact assessment; surveys and inventories; 
establishing a global list of biogeographic areas of particular importance for the conservation of biological diversity and a global list of species threatened with extinction on a global level; relationship with other international conventions; institutional measures on a national level; institutional arrangements for the convention itself; settlement of disputes: annexes and protocols and other procedural clauses. Since only three more meetings of the INC are scheduled to take place before the run-up to UNCED in June 1992, one wonders if it would be possible for the INC to clear the backlog by that time.

39. Something seems amiss with the negotiating strategy adopted to tackle the issues arising from the Draft Convention. Parts of the Draft Convention have been assigned to two Working Groups, Working Group I and Working Group II, for negotiations. While Working Group I has been assigned almost two-thirds of the Draft Convention Working Group II has been allotted Articles 14 to 19 which constitute the heart of the Convention. The successful elaboration of the Convention depends upon consensus being reached on the issues addressed in them. These provisions deal with access to genetic resources, access to and transfer of technology and funds and funding mechanisms. The impact of these provisions permeates the entire Convention.

40. Since progress in Working Group II is obviously slow on account of the contentious issues before it, the progress of work in Working Group I is also being adversely affected. Moreover, the Draft Convention itself suffers from being structurally haphazard in that while some of its provisions are duplicative and overlapping, others happen to be misplaced. This has quite often resulted in shunting of provisions from one Group to another entailing waste of precious time. Another factor that has contributed to unnecessary discussions is the lack of definitions of terms used in the Draft Convention which would be included in Article 2. The following terms and expressions should have specific connotations to facilitate the negotiations: conservation; species; endangered species; threatened species; species threatened with extinction; indigenous population; customary/traditional use; components of biological diversity; genetic material; genetic resources; country of origin or country providing genetic material and/or genetic resources. Furthermore, simultaneous negotiations proceeding in the two Working Groups has posed a problem especially for developing countries with a limited number of expert personnel which could mean not being able to be involved in the negotiations.

41. Fortunately, the UNEP has appreciated this difficulty and is providing financial assistance for their participation, even though limited to one or two persons from each least developed country. However, a more basic problem common to most of the governments is that since the issues of biodiversity are trans-sectoral, delegates, in general, do not understand the real issues at stake because of their orientation being basically sectoral. What is required is cross-sectoral terms negotiating for each country, but this is something which the developing countries cannot afford. For them the difficulties are further compounded because of the two negotiating forums. It is, therefore, felt that the stage has now been reached when negotiations should proceed in a single forum so that the required momentum could be generated to finalize the Draft Convention before the June 1992 deadline. A single forum would quicken the pace of negotiations since negotiators would have an integrated look at the overall Draft Convention and a better perspective of the outstanding problems so as to be able to find the corrective solutions.

42. The crucial points in the ongoing negotiations appear to be access to genetic resources (Article 14), transfer of technology (Articles 15 and 16) and funds and funding mechanisms (Articles 18 and 19). There is an intrinsic interlinkage between 
access to genetic resources and transfer of technology since the value of genetic resources depends on the technology to use them. For the most part, genetic resources are concentrated in developing countries and access to them has hitherto relatively been unrestricted whilst the technologies needed to exploit them are mainly with the industrialized countries which are protected by intellectual property rights. In view of the obstacles posed by the intellectual property systems to the diffusion of technology, the main fear of developing countries has been that industrialized countries want them to conserve their genetic resources in order to continue to exploit them. The developing countries have, however, become aware of the enormous value of their genetic resources and would like to have a trade-off with the industrialized countries so that in return for providing access to this resource they are able to secure relevant technologies so as to be able to build their own capability to maintain ex-situ collections including the use of technologies such as cryogenics (freezing techniques) and biotechnology. Biotechnology has tremendous potential for contributing to improved health care, food production, environmental problems and industry in developing countries. But it has potential environmental risks as well and it is not fully regulated in all countries. Concurrently, UNCED is developing international guidelines for assessment of risks of biotechnology. Therefore, before they acquire this sophisticated technology, developing countries would do well to install the requisite infrastructural facilities as well as to develop skills so as to be able to absorb it. The Convention needs to strike a right balance between national sovereignty over genetic resources and collective responsibility for conservation and rational use of biodiversity.

43. Another issue of vital importance relates to the provision of funds and establishment of funding facilities for the application of the Convention nationally and internationally. Article 18 of the Draft Convention requires the Contracting Parties to provide financial support for conservation of biodiversity according to the criteria to be decided upon by the Contracting Parties. One such criterion could possibly be the assessment of all States based on their GNP and transfer to biodiverse States on the basis of need.

44. Article 19 contemplates the establishment of a multilateral trust fund and cooperative arrangements with existing bilateral and multilateral sources of funding. Consequently, what is being envisaged is the setting up of a multilateral trust fund with an initial base of US $\$ 500$ million and an international corporation with initial funding of US $\$ 200$ million. An important requisite in this context is the reaching of an agreement on an order of magnitude for the finances needed during the first few years of operation of the Convention. At the third meeting of the INC in Madrid, an option considered was the UNEP-UNDP-World Bank's Global Environment Facility (GEF). The GEF which provides grants or highly concessional resources to developing countries to meet the cost of well-appraised conservation projects is being suggested by some countries as the main funding mechanism for the Convention.

45. Developing countries have, however, expressed apprehension about the operations of the GEF. The negative features pointed out about the GEF operations are that the UNEP has refused to put projects to GEF because it does not have clear environment assessment criteria; that a panel of experts to help with environment assessment has just been put in place, but developing countries do not have confidence in the panel of experts; they are good scientists but have little knowledge of development; and that the World Bank seems to consider grants of less than US \$5 million not to be worth while, whereas a lot could be done with smaller amounts of money. The positive feature about the GEF is that at least a mechanism has been set up and countries are contributing money. If GEF is envisaged as the funding mechanism for the implementation of the Convention, it would be crucial to detach it from suspicion.' 
57. Discussion of the item took place at a special meeting from 26 to 27 January 1992, during the Committee's Thirty-First session. The SecretaryGeneral introducing the item recalled that the Committee, at its TwentyNinth session in Beijing in 1990, while endorsing the future work programme in the field of the environment, had recommended that it participate actively in the preparatory phase of the United Nations Conference on Environment and Development scheduled to be held in Brazil in June 1992. Since then the AALCC Secretariat had drawn up an extensive programme to assist Member Governments in their preparations for UNCED which covered: (i) promotion of ratification of the 1982 UN Convention on the Law of the Sea and its subsequent implementation; (ii) transboundary movement of hazardous wastes and their disposal; (iii) consideration of issues before the Prepcom of UNCED, particularly Working Group III dealing with legal and institutional matters; (iv) assistance in the preparation of the Framework Conventions on climate change and on biodiversity; and (v) development of legal principles on environmentally sound and sustainable development. The Secretariat had monitored developments on these subjects in various forums and its findings were reported in the documents now before the Committee. In his view, because of the long-term nature of environmental protection, the Committee's concern and involvement should continue even after the conclusion of the Rio Conference, so as to include such activities as general assessment of the outcome of the Rio Conference; monitoring future stages of UNCED and follow-up of its new programmes with legal implications; preparation of analysis and comment on the Framework Conventions on climate change and biodiversity if adopted, monitoring developments after the signing of the Convention, and making recommendations thereon to Member States of the Committee in respect of ratification; studies on the further development of international environmental law; rendering assistance to Member States upon request in the field of national legislation concerning protection of the environment; and strengthening co-operation between AALCC and UNEP.

(a) Notes on major agenda items of Prepcom Working Group III, dealing with progress in drafting the 'Earth Charter/Rio Declaration' and with the survey of existing agreements and institutional issues (Doc. No. AALCC/XXXI/ ISLAMABAD/92/1) (summary of the discussions as reflected in Report, pp. 219-258)

58. There was general support for the Secretary-General's proposals concerning AALCC's role with regard to preparations for UNCED, participation at the Conference, and monitoring, study and assessment of subsequent developments.

59. The 'Earth Charter/Rio Declaration' should deal with the most urgent issues of environment and development, in particular those of importance to the developing countries including those relating to the right to a safe and clean environment, sustainable development, transfer of technology and funding. Among the central legal issues involved were those relating to (a) 
the concept 'common concern' or 'common heritage' of mankind, (b) State responsibility, (c) liability, (d) settlement of disputes and (e) the nature and status of the proposed charter/declaration. The text should be action-oriented and readily translatable into national legislation. The Prepcom should streamline its procedures and make every effort to reach consensus on the issues before it.

60. The developed countries during their period of industrialization, had caused the present degradation of the environment, and were also mainly responsible for its continued deterioration through their excessive exploitation and consumption of natural resources, and massive emission of pollutants. In most developing countries, poverty was the cause of environmental degradation, and protection of the environment in those countries could only be achieved through the eradication of poverty. Accordingly, for them, issues of economic development and environmental protection were inextricably linked.

61. For the developing countries, rapid economic development was the first priority. Accordingly, when asked to share the burdens of protecting and preserving the environment, and to allocate a portion of their scarce resources for such purposes, they could only do so to the extent that the diversion did not adversely affect their economic development programmes. For them, environmental protection would become feasible if they were to receive (a) new and additional financial resources, and (b) transfer of environmentally sound technologies on concessional or preferential terms.

62. While protection and preservation of the environment might be regarded as a common concern of all countries, the derived responsibilities should be differentiated. Thus, the application of environmental standards by developing countries should be in accordance with their respective capabilities. While the developing countries might undertake to incorporate environmental safeguards into their development plans, the developed countries should undertake to promote the economic development of through, for example, reduction of the external debt burden of the developing countries, or increasing financial flows to them.

63. It was important, moreover, that financial assistance not be subjected to unacceptable conditionalities; and equally, that environmental regulations not be used as tools in establishing non-tariff barriers in global trade. It was proposed that the Secretariat study and report on (i) tariff or non-tariff measures for the purpose of environmental conservation provided for both in national legislation, and in bilateral or regional agreements; and (ii) possible trade distortions through intellectual property rights in environmental technology.

64. The survey of existing international agreements and instruments concerning the environment should cover reasons for the reluctance of the developing countries to adhere to them, which would include the difficulty of implementing many of the commitments provided for thereunder. Thus, any action to promote ratification of treaties should be selective, and take into account the capabilities of States to implement the undertakings in 
those treaties. Proliferation of international agreements imposing a multiplicity of conditions relating to environmental protection represented an undue burden on the developing countries and should be avoided.

65. Similarly, proliferation of institutions dealing with environmental issues added to the difficulties of the developing countries and could be an obstacle to their effective participation in the global effort to resolve those issues. It was proposed that an international supervisory authority be appointed, charged with co-ordinating activities and programmes aimed at the prevention of further degradation of the environment.

(b) Draft Framework Convention on Climate Change (Doc. No. AALCC/ XXXI/ISLAMABAD/92/2) (summary of the discussions as reflected in Report, pp. 219-258)

66. The countries which had, during their period of industrialization, brought about widespread degradation of the environment, were also mainly responsible for the climatic changes which gave rise to the need for a convention. Accordingly, such a convention should include their commitment to providing the developing countries, for which rapid economic development was the highest priority, with financial assistance and environmentally sound technologies to enable them to participate effectively in international co-operation aimed at dealing with climate change, in accordance with their capabilities and without impairing their development efforts.

67. As to funding, the World Bank's Global Environment Facility (GEF) might be a step in the right direction, but was not enough. It should be supplemented, inter alia, by additional funds generated on the basis of the 'polluter pays' principle. In regard to transfer of technology, a re-definition of intellectual property rights was needed that would balance such rights with the developing countries' need for environmentally sound technologies. The development of human resources in those countries, including education and training, were also of importance in that connection.

68. In order that realistic and practicable strategies should be adopted by the developing countries within their capabilities and means, they should have access to the best scientific knowledge available. The Convention could establish an organizational mechanism which would serve such a purpose.

69. Consideration should be given to the particular situation of developing countries whose economies were heavily dependent on the export of fossil fuels. In that connection, the Convention should require the industrialized countries, which were the largest consumers of such fuels and currently responsible for the largest emissions of greenhouse gases, to reduce such emissions. 
(c) Draft Convention on Biological Diversity (Doc. No. AALCC/XXXI/ ISLAMABAD/92/3) (summary of the discussions as reflected in Report, pp. 219-258)

70. The decline of biological diversity due to human activity was proceeding at a rate that had given rise to concern, and could be irremediable. The developing countries were concerned that, while they were the main repositories of biological resources and had permitted relatively free access to them, the industrialized countries possessed the technology to exploit those resources, technology which was protected by intellectual property rights. Since the value of biological resources depended on the availability of technology to exploit them, the issue of access to the resources on the one hand, and issues relating to transfer of technology, funding and a funding mechanism for application of the Convention on the other, were among the most important awaiting negotiation at UNCED. The proposed Convention on Biological Diversity should strike the right balance between national sovereignty over biological resources and collective responsibility for conservation and rational use of biodiversity.

71. The Convention should, inter alia, make provision for the following: (i) an appropriate definition of the concept 'biological diversity' that would cover not only those species that are consumed by human beings and are considered to have economic value, but all species forming part of the web of life and are of importance for the support of life on the planet; (ii) recognition of national sovereignty of each State over its biological resources; (iii) direct linkage between conservation of biodiversity in developing countries and access to their biomaterials; (iv) protection and rewarding of local farmers, and of traditional, indigenous and informal innovations by local nationals; (v) access of developing countries to end products made from biomaterials from those countries, and to the relevant technologies; (vi) equitable sharing of research in biotechnology; (vii) equitable sharing of benefits and profits from the use of biomaterial, with the consent of the State of origin; (viii) transfer of technology to the developing countries on a preferential and non-commercial basis; (ix) new, additional and adequate funding for application of the Convention; and (x) equal emphasis on the rights and obligations of States.

\section{(d) Report of the AALCC Working Group on UNCED}

72. The open-ended Working Group established by the Committee (Rapporteurs: JAMSHED HAMID (Pakistan), AMRIT ROHAN PERERA (Sri Lanka); core membership: delegates of Arab Republic of Egypt, China, Ghana, India, Japan, Kenya, Libya, Pakistan, Sri Lanka) submitted a Report, to which was appended a Statement of General Principles of International Environmental Law. Based on a draft prepared by the Secretariat, the Statement attempted to reflect the views of as many delegations as possible. The Working Group agreed to place certain terms and expressions in brackets to accommodate the concerns of some delegations. The text of the Statement, which was later 
adopted unanimously at a plenary meeting of the Committee (Report, p. 213), ${ }^{20}$ reads as follows:

\section{STATEMENT OF GENERAL PRINCIPLES OF INTERNATIONAL ENVIRONMENTAL LAW}

The Asian-African Legal Consultative Committee after an exchange of views on legal aspects of environment and development affirms:

(i) that the environment is the common concern of mankind and that the environment and development are intrinsically and inextricably linked;

(ii) that the principle of sustainable development shall be given due effect and development shall not be pursued in a manner as would endanger the environment:

(iii) that all members of the international community shall ensure that no appreciable or significant harm is caused to the environment and that the environment does not suffer severe and irreversible degradation;

(iv) that the responsibility of member States of the international community shall be [common but differentiated] [differentiated] and the application and enforcement of environmental standards by the developing countries shall be in accordance with their respective capabilities and responsibilities;

(v) the need to protect inter-generation equities within the context of the progressive development and codification of international environmental law;

(vi) that the developed countrie in the interest of the common future of mankind and the protection and preservation of the environment, seriously consider making available to the developing countries [new] [adequate] and environmentally sound technologies on a [preferential and non-commercial] [fair and most favourable] basis;

(vii) that the developed countries, international and regional organizations and financial institutions consider, explore and, where necessary, make provision for [new] additional and adequate financial resources to the developing countries to meet the objectives of sustainable development and the protection and preservation of the environment;

(viii) that the UNCED should accord priority to the improvement and strengthening of the existing institutional mechanisms relating to environment and development in the United Nations system and to enhancing their cooperation and coordination; and

(ix) that any instrument to be adopted by UNCED should include appropriate provision for the peaceful settlement of disputes.'

\section{Decision 7 of the Committee}

73. The decision of the Committee on this item (Report, p. 114) relates to its work programme on the environment after the conclusion of UNCED, and reads, in part, as follows:

[The Committee's] suggested measures and actions to be taken in this regard may include:

20. Later reproduced in UNdoc./A/CONF.151/PC/WG.III/5. 
1. Preparation of a general assessment of the outcome of the Rio Conference concentrating particularly on the issues with legal implications;

2. Continue to monitor the ongoing process of UNCED at its next stage and follow up aspects of its new programmes with legal implications;

3. Preparation of detailed analysis and comments on the two Framework Conventions on Climate Change and Biodiversity if adopted, and monitor the developments after the signature of the Conventions, and make recommendations to the Member States of the Committee in respect of ratification of the Conventions respectively as deemed appropriate;

4. Make studies on the further development of international environmental law. An item, "Legal Aspects of the Protection of the Environment of Areas Not Subject to a National Jurisdiction (Global Commons)", might be taken up by the Committee. The topic will hopefully be included in the future work programme of the International Law Commission.

5. Render assistance to the member States at their request in the field of national legislation concerning the protection of environment; and

6. Strengthen the co-operation between the AALCC and the UNEP. In this regard the conclusion of a co-operation agreement between AALCC and UNEP should be considered.

\subsection{United Nations Decade of International Law ${ }^{21}$}

74. The Committee had before it a Note by its Secretary-General on the United Nations Decade of International Law (Doc. No. AALCC/XXXI/92/ 6) which presented an overview of the Committee's activities during the past year, and contemplated preparation of another set of notes and comments for transmission to the Office of Legal Counsel of the United Nations.

\section{Decision 8 of the Committee}

\section{The Committee's decision on the item (Report, p. 115), inter alia} $\therefore$

Reaffirms the importance of strict adherence to the principles of International Law as in the Charter of the United Nations;

Affirms that many of the political, economic and social problems between Member States can be settled on the basis of the law;

Decides that the item be given serious attention and steps be taken to place the same on the agenda of the meeting of the Legal Advisers of Member States of the Committee to be convened at the UN Office in New York during the Forty-seventh Session of the General Assembly;

Welcomes the various initiatives taken by Member States of the Committee in the implementation and observance of the Decade;

Requests the Secretary-General to apprise the Secretary-General of the United Nations of the initiatives taken by the Committee in this regard;

21. See 1 AsYIL (1991) 222. 
Requests Member States to continue to give serious attention to the observance and implementation of the Decade;

Directs the Secretariat to continue its efforts towards the success of the U.N. Decade of International Law;

\subsection{Trade Law: Work of the Sub-Committee on International Trade Law Matters $^{22}$}

76. The Committee took up for consideration four items dealt with by the Sub-Committee on International Trade Law Matters: (a) Legislative activities of United Nations and other international organizations concerned with international trade law; (b) Legal aspects of privatization; (c) Debt burden of the developing countries; (d) Proposal for the establishment of a Data Collection Unit.

\section{(a) Legislative Activities of the United Nations and Other International Organizations}

77. The Committee had before it a document prepared by the Secretariat, entitled 'Legislative activities of United Nations and other international organizations concerned with international trade law' (Doc. No. AALCC/ XXXI/ISLAMABAD/92/13) outlining work carried out on topics before the United Nations Commission on International Trade Law (legal guide for drawing up international countertrade contracts, model law on international credit transfers, model law on procurement, uniform law on standby letters of credit and guarantees, legal problems of electronic data interchange); the United Nations Conference on Trade and Development (international commodity agreements negotiated or renegotiated under UNCTAD auspices, international code of conduct on transfer of technology, multilaterally agreed equitable principles and rules for the control of restrictive business practices, model law or laws for the control of restrictive business practices and handbook on restrictive business practices legislation, and matters concerning maritime and multimodal transport, viz. charter parties, Review Conference on the UN Convention on a Code of Conduct for Liner Conferences, 1974 (1988, Resumed Session 1991), general average, UNCTAD/ICC rules on multimodal transport documents, multimodal transport and containerization, Draft Convention on Maritime Liens and Mortgages, and progress in ratification of the 1980 UN Convention on International Multimodal Transport of Goods, and the 1986 UN Convention on Conditions for Registration of Ships); the United Nations Industrial Development Organization (topics covered by the UNIDO 'System of Consultations', promoting contacts between industrialized and developing countries directed towards industrialization of the latter); the International Institute for the Unification of Private Law (UNIDROIT) (principles for international commercial contracts, the Hotelkeeper's Contract, international protection of cultural property, the

22. Cf. 1 AsYIL (1991) 224. 225, 227. See below, paras. 88-89. 
Franchising Contract, relations between principals and agents in international sales of goods, security interests in mobile equipment, civil liability connected with the carrying out of dangerous activities, and uniform rules on forwarding agency); and the Hague Conference on Private International Law (preparation of a convention on the law applicable to negotiable instruments, work on the law applicable to automatic data processing, contractual obligations in general, agreements on licensing of technology and transfer of know-how, and unfair competition, as well as revision of the 1965 Convention on the Service Abroad of Judicial and Extra-judicial Documents in Civil or Commercial Matters, and the 1970 Convention on the Taking of Evidence in Civil and Commercial Matters).

\section{(b) Legal Aspects of Privatization}

78. The Committee had before it a document prepared by the Secretariat at the request of the Sub-Committee entitled 'Legal aspects of privatization' (AALCC/XXXI/ISLAMABAD/92/14) intended, inter alia, to assist Member Governments to carry out the privatization programmes recently recommended by multilateral financial and monetary institutions in a manner not detrimental to national economic interests.

The document explains that most countries emerging from colonial rule and in search of a development model that would revitalize their economies, chose a 'mixed economy' in which primacy was given to the public sector, and the private sector was intended to play a complementary role. The rationale for this choice was that the State should ultimately determine economic policy, and that the welfare of the masses could be achieved only through socialism.

79. Although countries applying such development model achieved a degree of industrialization and self-reliance, overall performance by public sector enterprises (PSEs) was less than satisfactory, and has led to their becoming a severe financial burden to the State. Among the reasons for failure of PSEs are:

(i) Some of the PSEs have virtually become social welfare organizations with no accent on efficiency and productivity. They have become breeding grounds for corruption, patronage, inefficiency and bureaucracy, guzzling huge resources from the larger economy.

(ii) The PSEs are incurring continuous and staggering losses on account of their producing goods and services at high cost and of indifferent quality.

(iii) Their freedom of operation is severely curtailed due to excessive interference by Governments, formally or informally.

(iv) They have bred a culture of no work.'

Accordingly, multilateral financial agencies have recently urged (1) closure of chronically sick PSEs, and (2) re-organization or privatization of the remainder, and have made financial assistance available to meet the cost of retrenchment and monetary benefits for workers, with a view avoiding industrial unrest that might accompany closure of PSEs. 
80. Privatization and deregulation of the national economy has now become government policy in some 50 countries, including India, Pakistan, Sri Lanka, China and other countries of Southeast Asia, Angola, Algeria, Ethiopia, Kenya, Mexico, Chile and western and eastern Europe. Factors that led to this trend include (i) the success of privatization in the United Kingdom under Prime Minister Thatcher, (ii) the crumbling of economies that had relied on the public sector, such as those of eastern Europe, and their movement in the direction of privatization, (iii) movement away from the 'managing agency system' fostered under colonial rule, and the emergence of professional managers and a new entrepreneurial class, (iv) establishment of a substantial industrial and technological base and infrastructure, (v) growth of a capital market, and (vi) recognition that new industries like those concerned with micro-electronics, computers, and information technology may not necessarily benefit from State interference, and that withdrawal of the State from the economic process may be one of the keys to development. However, the manner and pace of privatization are important if adverse political consequences are to be avoided.

81. 'Privatization in essence means competition', and for the success of a programme of privatization there would have to be a restructuring of the economy and a fundamental change in the overall historical perspective. Four preconditions must be satisfied: (i) the economy must be globalized, and infra-national and international competition fully encouraged, (ii) subsidies must be abolished, (iii) price controls must be abolished, and (iv) internal and external protection through non-tariff measures must be abolished. However, poverty alleviation, equitable distribution of goods and services and maintenance of regional balances continue to be the major demands on governments, which have recourse to subsidies through the mechanism of administered and retention prices.

82. Accordingly, privatization is a long-term objective toward which governments should proceed in stages: (I) 'partial privatization' commencing with initial disinvestment of up to $20-25 \%$; (II) proceeding, in the case of selected viable PSEs up to $49 \%$ without waiting for major re-structuring of the economy, with the objectives of (a) improving efficiency, (b) making available funds for modernization, expansion and growth, (c) giving PSEs independence and making them accountable for performance, and (d) distancing the government from the day-to-day functioning of PSEs; (III) 'effective privatization' involved giving away control over the PSE, provided equity is distributed among a large number of shareholders, including the workers of the enterprise; (IV) 'total privatization' implying total withdrawal of the State from the enterprise. As to chronically sick PSEs, workers should be given the opportunity to run them, and, if this fails, they should be closed, appropriate measures being taken for rehabilitation and relocation of workers. Capital raised through disinvestment should be placed in a separate fund and utilized for (a) re-investment in the public sector for modernization, expansion and corporate growth, (b) assisting ailing PSEs and turning them around, (c) establishing a social security scheme to safeguard the rights of workers, and (d) intervention in the market to sustain public confidence in this equity. 
83. The legal aspects of privatization are addressed in the document, ${ }^{23}$ as follows:

$\therefore$

14. For implementing stages I and II of privatization, which can be characterized as partial privatization, there is already in place in most of the countries of the region the requisite legal framework, although a few changes will be required in certain legislation and a few items of fresh legislation may have to be enacted to create the new autonomous bodies to be entrusted with the task of facilitating and overseeing the process of partial privatization. At present, the equity of PSEs is not quoted at stock exchanges and therefore arrangements will have to be made to determine the sale and purchase price of their shares. For this appropriate changes and devices will have to be worked out in the Companies and Securities laws. Moreover, while embarking on a programme of progressive privatization, industrially sick units will have to be closed down which will result in massive retrenchment and unemployment of workers. Suitable amendments will have to be affected in the relevant industrial/labour laws to ease the cost of human adjustment.

15. For implementing stages III and IV of privatization, since the character of the PSE undergoes a transformation, considerable restructuring will be involved. Such restructuring will need a suitable legal framework. This legal framework generally includes constitutional guarantees and/or a law creating and respecting property rights, in which the term "property" is given the widest connotation; a law setting forth provisions for the transfer of property; a law regulating industrial development; a law relating to pollution prevention and environmental protection; a companies law; a contract law; an insolvency law; a securities law; a law of taxation on corporate incomes and dividends; an excise law (ad valorum and a value-added taxes); a competition law; and a set of industrial/labour laws regulating, inter alia, the treatment of employees in privatized enterprises.

16. Constitutional guarantees and/or a law creating and respecting property rights is a prerequisite because clearly defined property rights are an essential precondition of privatization. The law regulating transfer of ownership of land and businesses is required because almost all businesses to be privatized will involve the transfer of, or the right of use of, land from the State to the enterprises concerned. Such a law will provide whether companies with a certain percentage of foreign ownership can hold real property, and if so, under what conditions. The law relating to industrial development will specify the sectors which are reserved to the public sector and those which are open to the private enterprise. The prevention of pollution law, apart from checking pollution, will fix the liabilities for pollution damage caused by industrial accidents. The company law will specify the forms of business organisations (joint stock companies, both public and private, partnerships etc), confer separate legal personality on the business organizations and provide the extent of protection to investors from liabilities incurred by the business organisations in which they invest. The contract law is a sine qua non for commercial exchanges as it makes the contractual obligations binding on the parties to a contract. The insolvency law is necessary to deal with those businesses which fail to make a profit or are unable to continue to pay to their creditors. This will apply to private individuals as well as to businesses and will deal with the way in which outstanding creditors are paid for the pool of

23. AALCC/XXXI/ISLAMABAD/92/14 pp. 9 et seq. 
remaining assets. The securities law is required to create the necessary legal and regulatory framework within which the market for trading securities is established and made functional and to protect the interests of investors. Such a law will also lay down rules governing the operation of a stock-exchange and the information that must be disclosed by companies to obtain a listing on the exchange. The tax law, apart from taxing corporate incomes and dividends, will provide fiscal incentives for the establishment of new industrial enterprises. The competition law, an essential precondition for privatization, is intended to promote a healthy competitive environment and to ensure that PSEs, once privatised, do not maintain their monopolistic position. Side by side with the competition law, an independent quasi judicial body (such as the Monopolies and Restricted Trade Practices Commission in India) will have to be created to investigate and to implement the said legislation.

17. This body of laws may have to be complemented by a transformation law and a privatization law. The transformation law will be needed to facilitate the transfer of title to businesses from the State to the private sector. Such a law will provide that a PSE may be transformed either by the Government itself or by the management and/or workers with the permission of the Government. It might adopt either of the following two approaches: (i) the PSE may be transformed into a company, and once this has taken place the State will be the sole shareholder of the company and the shares may then be sold in the privatization process; and (ii) a new company will be formed and the government will contribute various assets together with the business as a going concern as its contribution to the capital. The remaining shares in the new enterprises may then be sold to raise finance for the running of the business.

18. A specific law on privatization will be necessary to empower the government to carry out the privatization programme. This is because under the Constitutions of many a State, a trade or industry can be nationalised by legislation and that too for a public purpose. From that it necessarily follows that a trade or industry can be privatised only by a specific enactment for that purpose and that such legislation must disclose the grounds on which public or community interest is better served by privatization. Moreover, in the case of those countries whose Constitutions ordain the State to function as a welfare State and vest the ownership of all means of production and natural resources in the State, a constitutional amendment may be necessary specifically providing that privatization is justified in public interest only when it leads to greater productivity, efficiency and development.' $\ldots$

84. Recognizing that social and economic conditions and existing legal parameters would vary among Member States of AALCC, and that the collection of relevant information from those States would be necessary in order to identify the policy and legal issues that could arise in connection with privatization, the Secretary-General with his letter dated 30 July 1991 circulated a questionnaire to Member States, inviting a response as soon as possible. By the opening of the Committee's Thirty-First session, only two States had responded. The Secretariat's questionnaire is reproduced below, together with the response of Singapore, chosen by way of example, for its completeness.

$\therefore$

\section{ASIAN-AFRICAN LEGAL CONSULTATIVE COMMITTEE QUESTIONNAIRE}

1. What have been the social, economic and political factors which have led your Government to go in for privatisation? 
2. How is the term "privatisation" defined in your country?

3. What aims has your country set for privatisation?

4. What is the precise sphere of privatisation (sectors and industries)?

5. What are the economic, financial, fiscal and legal preconditions for privatisation in your country?

6. The basic methods and procedures for privatisation appear to be as follows:

(i) Private sale of shares - In this, the State sells all or part of its shareholding in a wholly-or partly-owned State enterprise to a pre-identified single purchaser or group of purchasers.

(ii) Public offering of shares - In this the State sells to the general public or to a limited class of purchasers all or large blocks of stocks it holds in a wholly or partly owned State enterprise.

(iii) Managment/Employees Buy-out - This refers to the acquisition of controlling shareholding in a company by a small group of management and/or employees.

(iv) Sale of assets - This involves sale of particular assets (trademarks, plants, etc.) rather than shares in a going concern.

(v) Restructuring - This involves the breaking-up of a State-owned enterprise into several subsidiaries.

(vi) New private investments - In this modality, the State does not dispose of its existing equity in a public undertaking, but increases overall equity and causes a dilution of the Government equity.

(vii) Leases and Management Contracts - These are arrangements whereby private sector management, technology and/or skills are provided under contract to a Stateowned undertaking or in respect of State-owned assets for an agreed period and compensation.

Which of these modalities are adopted in your country for privatisation and what have been the legal problems encountered in that regard?

7. Has your Government set up a statutory body to supervise privatization process? If so, what is its role, rights and obligations?

\section{RESPONSE OF SINGAPORE}

\section{Answer to Question I}

The rationale for our privatisation programme is as follow:

(a) To withdraw from commercial activities which no longer need to be undertaken by the public sector;

(b) to add breadth and depth to the Singapore stock market by the floatation of government linked companies and statutory boards and through secondary distribution of government-owned shares; and

(c) to avoid or reduce competition with the private sector.

\section{Answer to Question 2}

The initial sale of shares of a subsidiary that has hitherto been wholly-owned by the Government is "partial privatisation". The sale of shares of a partially privatised company is "further privatisation", sale to the extent of giving away control of a company is "effective privatistion" and complete withdrawal from a company is "total privatisation".

\section{Answer to Question 3}

Please see answer to Question 1. 


\section{Answer to Question 4}

The Government has shareholdings in a very diversified group of companies. Our policy is to privatise as many companies as possible.

\section{Answer to Question 5}

Companies which are privatised through public floatation must satisfy the listing requirements laid down by the Stock Exchange of Singapore. Please see attachment.

\section{Answer to Question 6}

We do not restrict ourselves to any one particular method, as we have to look at the situation and circumstances of each case of privatisation. We have not encountered any major legal problems so far.

\section{Answer to Question 7}

No.

[Attachment to response of Singapore]

ORIGINAL LISTING REQUIREMENTS

\section{A. Criteria for Original Listing}

\section{General}

The approval of an application for the listing of securities on the Stock Exchange of Singapore Limited is a matter solely within the discretion of the Exchange.

The Exchange has established certain numerical standards, set out below, which will be considered in evaluating potential listing applicants. Aside from the numerical standards set out below, there are, of course, other factors which must necessarily be taken into consideration in determining whether a Company qualifies for listing. A Company must be a going concern or be the successor of a going concern. While the amount of assets and earnings and the aggregate market value are considerations, greater emphasis is placed on such questions as the degree of national interest in the Company, the character of the market for its products, its relative stability and position in its industry, and whether or not it is engaged in an expanding industry with prospects of and/or maintaining its position.

\section{Ordinary Shares}

Companies applying for quotation of ordinary shares are, as a general rule, expected to meet the following criteria:

(1) It has a paid-up capital of at least $\$ 4,000,000$.

(2) At least $\$ 1,500,000$ or 25 per cent of the issued and paid-up capital (whichever is the greater) is in the hands of not less than 500 shareholders.

(3) A minimum percentage of the issued and paid-up capital is in the hands of shareholders each holding not less than 500 shares and not more than 10,000 shares:

Nominal value of issued and paid-up capital

less than $\$ 50$ million

$\$ 50$ million and above and less than $\$ 100$ million

$\$ 100$ million and above

\section{Minimum percentage}

$20 \%$

$15 \%$ or $\$ 10$ million whichever is the greater

$10 \%$ or $\$ 15$ million whichever is the greater 
In complying with this distribution, the following are to be excluded:

(a) Holdings by parent, or companies deemed to be related by virtue of Section 6 of the Companies Act.

(b) Holdings by directors (including those of persons designated directors under the Companies Act).

(4) Except in very exceptional circumstances, the Exchange will refuse a quotation to partly paid shares, and even, should such a quotation be granted to such partly paid shares, the Exchange may impose such restrictions on the dealings in such shares.

\section{Bonds, Debentures and Loan Stock}

A Limited Liability Company seeking official quotation of Loan Securities may be considered for admission to the Official List if:

(1) It has at least $\$ 750,000$ of issued loan securities of the class to be quoted;

(2) There are at least 100 holders of such securities;

(3) The securities are created and issued pursuant to a Trust Deed, which must comply with the Trust Deed requirements of the Exchange as set out in Part $\mathrm{X}$, the trustee of which is:

(a) A company authorised by the law of Singapore to take in its own name and grant of Probate or Letters of Administration of the estate of a deceased person;

(b) A company registered under any law of Singapore relating to Life Insurance;

(c) A banking company;

(d) A company of which the whole of the issued shares are beneficially owned by one or more companies referred to in (a), (b) and (c) above;

(e) A company approved for this purpose by the Government of Singapore as trustee for the holders of such securities.

\section{Securities of Foreign Companies}

The requirements for admission to the Official List of foreign companies shall be prescribed by the Exchange from time to time and such requirements shall be published as "Guidelines for the listing of foreign companies".

\section{Exploration and Development Companies}

An application for listing from a Company whose current activities consist solely of exploration will not normally be considered, unless the Company is liable to establish:

(1) The existence of adequate reserves of natural resources which must be substantiated by the opinion of an expert in a defined area over which the Company has exploration and exploitation rights, and

(2) An estimate of the capital cost of bringing the Company into a productive position, and

(3) An estimate of the time and working capital required to bring the Company into a position to earn revenue.

\section{Property Investment/Property Development Companies}

The Exchange generally will not list a property Company unless a valuation of the freehold and leasehold property of the Company or the Group (such as the case may be) has been conducted by an independent professional valuer on a date which should be not more than six months from the date of the Company's application to the Exchange for quotation.

\section{Special types of Companies}

(1) Companies with good prospects for growth and are in need of raising capital may be considered for listing notwithstanding that they have yet to establish any track record or otherwise unable to comply with any of the listing requirements of the Exchange. The Exchange will take into consideration all pertinent factors, particularly with regard to the quality and expertise of the management and/or board of directors of the companies. 
(2) If, in the opinion of the Exchange, a Company, seeking admission to the Official List is engaged in a business or activity which is peculiar to a particular trade and for which the requirements of the Exchange may not be totally applicable, the Continuing Listing Requirements of the Exchange in general and the Directorate Requirements in particular, may be amended to bring the requirements more in line with the nature or activity of the company.

\section{B. Policies}

\section{Conflicts of Interest}

The existence of material conflicts of interest between Companies and their officers, directors or substantial shareholders (or members of their families or concerns controlled by them) will be reviewed by the Exchange on an individual basis in considering the eligibility of Companies for original listing. In many cases, Companies may be able to eliminate conflicts situation prior to listing within a reasonable period after the listing and may be asked to do so. Where a conflict cannot be resolved promptly for some business reasons, the Exchange will consider all pertinent factors.

The most common types of conflict situation to which this policy applies include personal interests of officers. directors or principal shareholders in any business arrangements involving the Company, such as the leasing of property to or from the Company, interests in subsidiaries. interests in business that are competitors, suppliers or customers of the Company, loans to or from the Company, etc.

In considering the eligibility of Companies applying for original listing under its conflicts of interest policy, the Exchange considers, among other factors:

(1) persons involved in conflict and relationship to the Company;

(2) significance of conflict in relationship to the size and operations of the Company;

(3) any special advantage for management involved in the conflict;

(4) whether the conflict can be terminated, and if so, how soon and on what basis, and, if the conflict cannot be promptly terminated, whether:

(a) the arrangement is necessary or beneficial to the operations of the Company;

(b) the terms of the arrangement are the same or better than those that can be obtained from unaffiliated concerns;

(c) the arrangement has been approved by independent directors or shareholders:

(d) the arrangement has been adequately disclosed to shareholders through prospectus, proxy statements or any reports.

In some cases, the Exchange will require a Company to enter into a special arrangement with the Exchange. designed to reduce the possibility of a conflict situation that could not be terminated immediately.

\section{Memorandum and Articles of Association}

Companies seeking admission to the Official List of the Exchange are required to incorporate into their Memorandum and Articles of Association various provisions which are set out in Part IX of this Manual.

\section{Additional Requirements}

\section{Original Listing Application}

Companies seeking admission to the Official List must submit an application for original listing in accordance with Part II of this Manual. Application for original listing is designed to serve the purpose of placing before the Exchange the information essential to its determination as to the suitability of the securities for public trading on the Exchange.

\section{Prospectus}

All Companies seeking admission to the Official List of the Exchange, whether through a 
public issue, Offer for Sale or an Introduction, must issue a prospectus which must, in addition to complying with the prospectus requirements of the Companies Act, comply with the prospectus requirements of the Exchange as set out in Part VII.

\section{Additional Listings}

Following listing. Companies and their registrars are not permitted to issue any securities in excess of those authorised for listing until the Exchange has approved an additional listing application covering the additional securities as described in Part IV.

\section{Listing Undertaking}

Companies applying for listing on the Exchange are required to enter into an Undertaking with the Exchange to comply with all the listing requirements and policies of the Exchange (See Appendix I).

\section{Allotment of shares reserved for employees etc.}

Companies seeking admission to the Official List may be permitted by the Exchange to reserve up to $10 \%$ of the offered shares for allotment to their employees, executive directors, customers, suppliers, etc. provided that the companies lodge with the Exchange a statement giving number of shares to be allotted to the following categories of persons and the basis of allotment:

(a) employees;

(b) executive directors;

(c) customers;

(d) suppliers; and

(e) others (state relationship with issuer).'

\section{(c) Debt Burden of the Developing Countries}

85. The Secretariat's document on the debt burden of developing countries (Doc. No. AALCC/XXXI/ISLAMABAD/92/16, the latest in a series of its studies of the subject, outlines the origins of the debt crisis facing the developing countries, and discusses various solutions proposed before the United Nations, GATT, UNIDO, UNCTAD, and the EC, proceeding thereafter to examine the legal aspects of 're-scheduling' and to suggest guidelines for developing countries engaging in the process as well as related renegotiation of loan agreements.

(d) Research and Development of Legal Regimes Applicable to Economic Activities in Developing Countries

86. Document AALCC/XXXI/ISLAMABAD/92/17 contained a proposal by the Secretary-General for the establishment of a Data Collection Unit as an integral part of the AALCC Secretariat, in implementation of a proposal made by the Republic of Korea at the Committee's Nairobi session (1989). ${ }^{24}$

Having recalled the proposal of the Republic of Korea for the establishment under the auspices of AALCC, of a 'Centre for Research and Development 
of Legal Regimes applicable to Economic Activities and Changing Situation of the Afro-Asian countries', and that Government's willingness to contribute financially to the project, the Secretary-General suggests that establishment of such a Centre as an autonomous institution would require considerable financial outlays, preparatory work and acquisition of expertise. Thus, while establishment of an autonomous Centre should remain the long-term objective, a first practical step would be to set up a Data Collection Unit as an integral part of the Secretariat. The Secretary-General's proposals regarding staff and equipment for the Unit, as well as for financing its operation during 1992 and 1993 from the remainder of a grant made by Korea, are set out in the document.

87. The documents referred to in paragraphs $77-86$ above were considered by the Sub-Committee on International Trade Law Matters, which also had before it a letter from the Secretary of UNCITRAL concerning a Congress on Uniform Law in the Twenty-First Century, to convene in New York from 18 to 22 May 1992, and inviting AALCC to make a contribution on the topic 'Value of universal unification for regional integration and development'.

88. After discussion of the documents before it, the Sub-Committee submitted a Report recording its decision to recommend to the plenary, inter alia, (i) that it request the Secretary-General to prepare a practice-oriented paper on the topic 'Value of universal unification for regional integration and development' as a contribution to the Congress referred to; (ii) that, as the topic 'Privatization' had acquired immense importance for the developing countries, it should urge Member Governments which had not responded to the Secretary-General's questionnaire on the topic to do so as early as possible and/or to furnish any relevant documentation to the Secretariat; and (iii) that, as a Data Collection Unit was likely to be set up soon as in the AALCC Secretariat, it should request the Secretary-General to take the necessary steps to conclude co-operation agreements between AALCC and other international and regional organizations active in the areas of international trade law and economic relations so as to stimulate the flow of information to the Data Collection Unit (Report, pp. 98-101).

89. The Report of the Sub-Committee was adopted unanimously at the Committee's Plenary session (Report, p. 213). 